\title{
John William Colenso's Collection of Psalms and Hymns for St Peter's Cathedral, Pietermaritzburg: Context, Analysis and Christological Implications
}

\author{
Andrew-John Bethke \\ https://orcid.org/0000-0002-6240-6239 \\ University of KwaZulu-Natal \\ bethkea@ukzn.ac.za
}

Abstract

In 1866, Bishop John William Colenso published a collection of hymns which he compiled for use at St Peter's Cathedral in Pietermaritzburg. He had recently returned to Natal from England after defending himself in the legal debates which surrounded his status as Bishop of Natal. His controversial commentaries on Romans and the Pentateuch had been the catalyst of his denouncement by his metropolitan bishop, Robert Gray. While Colenso had been in England, Gray had visited the Diocese of Natal. While there, he introduced the recently published Hymns Ancient and Modern to parish churches. Colenso was a strong critic of Hymns Ancient and Modern, mainly on account of its ritualist tendencies, and he was annoyed to find that Gray had introduced the book in his absence. In response, he created a collection of hymns, a number of which he edited in order to conform to his evolving Christology. The collection sparked something of a media frenzy both in Natal and Britain, so much so that it was still being discussed four years after Colenso's death. This article provides the historical context of the collection and its subsequent revisions; an analysis of its contents, paying special attention to hymns that were modified in some way; and a critique of the letters and reviews the collection received in the press. The article suggests that Colenso's notoriety ensured that the collection received far more attention than it warranted. In essence, it served as a proxy battle ground for deeper concerns about the impact of biblical criticism on Christology.

Keywords: Colenso; Anglican hymnody; Christology; Colonial Anglicanism; hymns ancient and modern

\section{Introduction}

In 2018, while researching Anglican ritualism in South Africa, I unexpectedly came across references in Darby (1977) to Colenso's 1866 collection of metrical psalms and

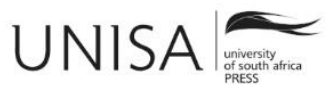


hymns for St Peter's Cathedral in Pietermaritzburg. The collection received a brief analysis in Darby's thesis; but after further investigation, I discovered a series of articles in the local and international press related to the collection initiated primarily by Anglican high church and ritualist clerics in both colonial Natal and England. That a small collection of psalms and hymns intended for one congregation could attract international attention reveals the extent to which Colenso's theological ideas were being scrutinised by lay people and ordained clergy alike. This article provides a brief literature review in relation to the collection. Then it examines the context in which the collection was assembled and received, with particular attention to the Christological concerns highlighted by Colenso's critics. My primary sources for this section are contemporary newspapers and letters. Thereafter I analyse the first edition of the collection, assessing the criticisms against it, as well as the changes Colenso made in succeeding editions in response to these criticisms. Finally, I explore the reprise of criticism against the initial edition, as well as the vociferous defence of Colenso by lay people, which emerged in the late 1880s. My argument in the latter half of the article is that the theological worldviews of Colenso and those who opposed him were on opposite sides of the theological spectrum. It was, thus, the theological debate around Christology which was the actual issue, rather than Colenso's psalm and hymn collection per se.

\section{Literature review}

Besides the nineteenth century primary sources, newspaper articles, reviews, sermons and letters, which discuss the hymn book directly and which are analysed below, there is very little in the way of analysis in existing academic literature. Colenso's biographer, George William Cox (1827-1902) ${ }^{1}$ includes a letter by Colenso to William Henry Domville (1819-1898) which mentions the hymn book in passing (Cox 1888, 23). However, Colenso's antipathy towards Hymns Ancient and Modern appears several times, setting the context for the genesis of his psalm and hymn book (Cox 1888, 38 and 100ff). In more recent times, especially from the 1960s onwards, renewed academic interest emerged in Colenso's mission practice and biblical criticism, particularly as the centenary of his death approached in 1983. In this corpus, only Ian Darby's work provides a glimpse of the contents of the collection (Darby 1977, 122-123). Peter Hinchliff (1964), while providing a thorough historical and theological perspective of Colenso's ministry, does not discuss the hymn book directly. However, like Cox, he does write about Colenso's feelings concerning Hymns Ancient and Modern (Hinchliffe 1964, 175). Jeff Guy's (1983) important biographical work does not discuss or examine the hymn book, neither does he list it among Colenso's publications. Perhaps he thought it too peripheral. The major supplementary source to Guy is a collection of essays edited

1 Cox was an English priest and historian. Initially he was influenced by the Oxford Movement and as a result was ordained as a priest. He travelled with Colenso to Natal in 1853-1854 when the new bishop visited his diocese. His religious views changed dramatically as he interacted with Colenso and Maurice. 


\section{Bethke}

by Jonathan Draper (2003), which lists one of Colenso's earlier psalm and hymn collections among his publications, but does not refer directly to the hymn book in the main text.

\section{Historical Context}

Psalms and Hymns for Use in the Cathedral Church of St Peter's, Maritzburg and in the Diocese of Natal (hereafter Psalms and Hymns) was advertised for sale by the Pietermaritzburg publisher, Davis and Sons, in The Natal Witness on 8 March $1866 .{ }^{2}$ This was a significant year for Colenso. He returned to Natal from England in late 1865, having defended his commentaries on Romans (first published in 1861) and the Pentateuch and Joshua (published in four volumes between 1862 and 1877). The robustness of Colenso's arguments against the veracity of biblical historicity, particularly in terms of numbers of people participating in the exodus and the ensuing desert interregnum, caused a theological furore which engulfed much of the Englishspeaking world. On the one hand, those who were horrified that the correctness of the biblical witness could be openly challenged, sought to defend biblical inspiration. On the other, those influenced by the scientific discoveries of the nineteenth century, particularly related to Darwin's On the Origin of Species (published in 1859), sought a brand of spirituality which did not deny the difficulties of biblical contradiction and paradox, but valued a scientific quest for truth through faith, and included those whose beliefs fell somewhere in between. Those who identified themselves as scientific intelligentsia and who remained broadly within the realm of Christianity seemed to appreciate Colenso's thorough, if clinical, treatment of the biblical text. Many of them came to his defence in the debates which surrounded Colenso in the international press. But beyond the religion and science debate, Colenso's views on biblical inspiration tested the boundaries of Anglican tolerance to their limit at the time. For a denomination which had a long tradition of Calvinistic worship, questioning the foundation upon which almost the entire faith was based seemed like a massive blow to established theologising, preaching, sacramentality and mission. Colenso represented an advanced guard of liberalism which the conservative old-guard (particularly represented by high church bishops) sought at all costs to silence.

Thus, when Colenso returned to his diocese to find that his authority had all but been rejected by most of the local clergy, he was particularly defensive of his views, and also began testing even newer avenues of interpreting scripture. For example, in early 1866, he began to believe that the Bible did not teach that prayers and worship should not be addressed directly to Christ, but rather through Christ to God. ${ }^{3}$ This lit a new spark in

2 The advertisement reads as follows: "Just Published, Psalms and Hymns for use in the Cathedral Church, Maritzburg. Printed under the direction of the Rt. Rev. the Lord Bishop of Natal. P. Davis and Sons, Publishers. Maritzburg, 8 March 1866" (Natal Witness, Tuesday 13 March 1866).

3 For a full exposition of Colenso's thinking regarding this theological tenet, see Colenso 1868a, 142153. 
the anti-Colenso ferment in England at the time. As so often happens, Hymns Ancient and Modern and Psalms and Hymns, were simply the proxy battle grounds for larger theological and dogmatic arguments.

While Colenso was away in England, Bishop Robert Gray of Cape Town (1809-1872) had visited Natal to try to re-establish "order" in the wake of Colenso "apostasy." During the visit, he had introduced Hymns Ancient and Modern (first published in 1861, hereafter HAM) as the preferred hymnal. Colenso reacted strongly against this imposition in his episcopal see. In light of his belief about the worship of Christ, he found a number of hymns in HAM offensive (Cox 1888, 38-39), not only because they openly worshipped Christ, but because "they are wanting in practical character; or they are written in bad taste, using familiarly that name 'at which every knee should bow,' and every heart do reverence; or they are a channel for putting forward extreme doctrine, on either side, which are not accepted by all devout worshippers ..." (Colenso 1868a, 152). He also found that in some hymns "... 'the very thorns, and cross, and nails, and lance,' the wounds, the vinegar, the gall, the reed, are called upon to satisfy our spirits, to fill us with love, to plant in our souls the root of virtue, and mature its glorious fruit [italics original]" (Colenso 1868a, 150). Here Colenso was referring to the English translation by John Mason Neale of Aquinas' Pange Lingua (hymn no, 96 in HAM). Many middle-of-the-road Anglicans of the mid-nineteenth century would also have found such hymns and their sentiments worrisome or offensive.

Colenso provided a thorough and, to some, sound apology for his dislike of HAM through his sermon on prayers to Christ, which was subsequently published (Colenso 1868a). As we will see below, his sermon also tried to answer the criticisms that Psalms and Hymns had received in The Natal Witness. But was the psalm and hymn collection actually a theological statement against HAM, or was it simply an attempt on Colenso's part to reassert his authority in the Diocese of Natal over and against Gray? At this distance in time, it is difficult to discern. A letter Colenso wrote to Cox on 3 April 1866 could suggest that Colenso was simply mitigating Gray's intrusion into his diocese (Darby 1977, 121-122). But he also wanted "to make a small collection as different in spirit as possible from "Hymns Ancient and Modern" (Darby 1977, 122). Although HAM was conceived by high church and ritualist editors, its target audience was described as "comprehensive" (Rainbow 2001, 293; Temperley 1979, 298). It took root in numerous parishes of varying theological views as the nineteenth century progressed, even though some of its content was decidedly Catholic in nature, but in its early days it was a badge of high churchmanship. Colenso is said to have lauded the Tractarians and their followers (sometimes called "high churchmen") for encouraging ordinary people to think carefully about their faith, but he rejected aspects of their theological stance and practice (see Guy 1983, 57). In essence, then, while it seems completely plausible that Colenso compiled the psalm and hymn collection in order to follow his theological teachings through fully, he was probably reacting against Gray and his introduction of a hymnbook, which represented the antithesis of his authority. 


\section{Bethke}

\section{Colenso and Singing in Christian Worship}

Colenso appears to have been deeply invested in public psalm and hymn singing (Darby 1977, 120), and thus busied himself throughout his career assembling compilations of metrical psalms and hymns for congregational and private use. He even translated some hymns into Zulu (Darby 1977, 120). But despite being a lover of both psalms and hymns, he was deeply cognisant of a number of issues which faced anyone who compiled collections for congregational use. For example, he was aware that hymnody could impart theological teachings, both good and bad, very effectively (Colenso 1868a, 142-153). Additionally, he was conscious of the fact that hymnody (not being a direct allusion to, or quotation from scripture) did not legally have a place in the Church of England liturgy (Colenso 1868a, 152). ${ }^{4}$ Nonetheless, this did not stop him from adding his own distinctive collections to the vast corpus of Victorian English collections of congregational texts.

Darby $(1977,120)$ lists three psalm and hymn collections which Colenso compiled in his lifetime: 1) A Selection of Psalms and Hymns; for Public and Family Worship, in the Church of England; 2) Psalms and Hymns for Use in the Church of England, at Home and in the Colonies (hereafter PHCE) ${ }^{5}$; and 3) Psalms and Hymns discussed in this article. However, I have not been able to find a copy of Darby's first mentioned source. A review of Colenso's psalm and hymn collections from The Church Times $(1866,326)$ implies that he only published two collections. It is possible that he published a collection for Forncett (the parish where he ministered before being consecrated as a bishop) and used the same collection in Natal. Whatever the case, PHCE mirrors trends in hymnody in England at the time quite closely, ${ }^{6}$ but Psalms and Hymns departs in character from PHCE, primarily in design, but also in aspects of the content, which are discussed below.

4 For a full analysis of the legality of singing hymnody (as opposed to psalmody) in public worship in the Church of England, see McCart (1998).

5 Accessed 21 January 21, 2021.

https://books.google.co.za/books?id=jQ0DAAAAQAAJ\&pg=PP3\&source=gbs_selected_pages\&cad $=3 \# \mathrm{v}=$ onepage $\& \mathrm{q} \& \mathrm{f}=$ false .

6 Despite the meteoric rise in hymnody in the first half of the nineteenth century in England, metrical psalmody was still incredibly popular. While the numerous new collections of psalms and hymns included ever growing numbers of hymns, a large selection of metrical psalms was always included (Temperley 1979, 227-233). In fact, the metrical psalms usually appeared as a separate section at the beginning of these collections. It was only as the nineteenth century progressed that the number of hymns began to outnumber the psalms. As more and more material became available, so clergy actively assembled those they felt were appropriate for their local congregations. Colenso's early collections can be numbered along with these locally created collections. Like many of those in use in England, PHCE separates metrical psalms and hymns (as was customary). It also includes numerous hymns from non-Anglicans such as Watts, Wesley and Montgomery. 


\section{Bethke}

\section{Description and Analysis of Psalms and Hymns}

The original 1866 edition of Psalms and Hymns is not available in any South African libraries or archives, but astonishingly, it is available online. ${ }^{7}$ A second, slightly enlarged, edition, was released in $1867 .{ }^{8}$ It included only seven additional hymns, all taken directly from the Book of Common Prayer. A third revision was issued in 1868 with 40 more hymns, and several doxologies in different metres. ${ }^{9}$ These additions were included as a type of appendix in alphabetical order. The doxologies were not numbered. It seems, as I will show below, that these two later editions were a response to the criticisms levelled at the first edition, with the third edition offering the more comprehensive response.

The first edition has 152 separate texts, arranged in alphabetical order, with the psalms and hymns placed together rather than in separate sections. While mixing psalms and hymns was not common at the time, HAM had also adopted this format, and after that it became quite common for hymns and psalms to appear together thematically. Colenso's edition is not ordered according to the church calendar, as many earlier collections were, but does include a table of suggested hymns for particular occasions.

The table is interesting in that it omits two familiar festivals. Consider the omission of the Epiphany. This festival celebrates the revelation of Christ as God and the lectionary readings focus on events which point to Christ's divinity. By leaving out the Epiphany, was Colenso implying that he intended not to commemorate Christ's divinity? He does not offer a reason for its omission, but it cannot have been a mistake, because in all the subsequent editions it was also left out. The Ascension was also omitted. It could be argued that in the ancient church, Ascension and Pentecost were sometimes celebrated together, but there is no evidence to suggest that Colenso accepted this liturgical position. What did the omission of the Ascension infer? Often the Ascension is associated with Christ being raised and subsumed into the Godhead in heaven. In his Natal Sermons, Colenso did not give any indication that he denied the Ascension. Indeed, he speaks of "the glory of our Lord's Ascension" (Colenso 1868a, 124). From his sermon on "Spiritual Resurrection" he seems to indicate that ordinary Christians, through faith, also ascend to God's presence, though hidden in Christ (Colenso 1868a, 122-131).

7 Accessed 21 January 21, 2021.

https://books.google.co.za/books?id=c1JVAAAAcAAJ\&pg=PT1\&source=gbs_selected_pages\&cad $=2 \# \mathrm{v}=$ onepage $\& \mathrm{q} \& \mathrm{f}=$ false .

8 Accessed January 21, 2021. https://books.google.co.za/books?id=dVJVAAAAcAAJ\&pg=PA1\&source=gbs_selected_pages\&cad $=2 \# \mathrm{v}=$ onepage $\& \mathrm{q} \& \mathrm{f}=$ false.

9 Accessed January 21, 2021. https://books.google.co.za/books?id=LlhDxwEACAAJ\&pg=PA1\&source=gbs_selected_pages\&cad $=2 \# \mathrm{v}=$ onepage $\& \mathrm{q} \& \mathrm{f}=$ false. 


\section{Bethke}

Why then omit hymns for the Epiphany and Ascension? Hinchliff $(1964,44)$ described Colenso's theological view early in his career as kenotic Nestorianism; that is, in complete humility Christ descended from the Godhead (kenosis, or self-emptying, see Philippians 2:6-11) ${ }^{10}$ was born fully human and in his humanity contained both human and divine natures. However, in Nestorian thought the two natures were not hypostatically intertwined, as orthodox Christianity claimed, but instead separate within the confines of the human body. If this was Colenso's position, he might have considered the feast of the Epiphany too much of a magnification of Christ's divine nature, as opposed to Christ's humanity. With the Ascension, it may have depended on how Christ's ascent to the Godhead was interpreted. If only the divine part of Christ was ascending, then Colenso may have argued that the Ascension denied Christ's humanity. However, the Ascension could also be interpreted as both the divine and human natures being lifted into the Godhead, thus sanctifying the human condition before God. Colenso's teachings about Christ as the ultimate human exemplar of God's love suggest that all Christians have the privilege of experiencing God's presence because of Christ's ascension - thus, all humankind has the potential of "ascending." Perhaps this radical egalitarianism of Christ and humankind prompted Colenso to dispense with the feast as a celebration of Christ's ascension and instead concentrated on the spiritual resurrection he claimed all Christians experienced through baptism. Even when he tempered his view about prayers to Christ later in his ministry, in the revised editions of his psalm and hymn collection, he still omitted the Ascension. On a practical level, perhaps Colenso could not find hymns appropriate for Ascension which matched this theological point of view.

Two other omissions in this table are noteworthy. Neither of the two cardinal sacraments is assigned any hymns. Some of Colenso's antagonists felt that this signalled his dismissal of the church's sacraments. However, as his Natal Sermons (Colenso 1868a) illustrate, this is not the case whatsoever. There is, perhaps, a suitable explanation for these omissions. At the time, Communion services were not usually observed weekly or daily. They tended to take place quarterly in most congregations. Also, these quarterly Communion services were often celebrated on special feast days like Christmas, Easter and Pentecost. Hymns for such occasions were already assigned by Colenso. Likewise, baptisms tended to be private affairs which took place after the main service on a Sunday (quite often on Sunday afternoons) or during the week. The congregation was usually just the family and perhaps some friends. In such cases hymns were not practical. Thus, omitting such sacraments was not necessarily a denial of their existence or efficacy, but possibly simply a pragmatic decision.

It is likely that the 1866 edition was based on Colenso's earlier collection. Of the 152 psalms and hymns in Psalms and Hymns, 148 also appear in the earlier compilation.

10 In some kenotic theologies, in the process of becoming human, Christ loses some of the divine nature. 
Thus, it seems that he was reviewing his earlier work in light of his most recent theological position. Given that his first collection had in excess of 350 texts, the large number of psalms and hymns that he omitted appears to suggest that he was fairly determined to apply his theological tenets.

Colenso, like other reformers before him, regarded scripture as one of the most appropriate sources for congregational song (Colenso 1868a, 152). In this regard, he was akin to Calvin, but not quite as rigid, because he allowed for the use of hymns, as long as they met certain criteria. Nevertheless, it is not surprising that the title of the 1866 collection begins with "Psalms" and the bulk of texts are metrical psalms or paraphrases. Altogether there are 92 metrical psalms or paraphrases of the psalms (about $61 \%$ of the collection). Of these, 49 are from Tate and Brady's "New Version" of the metrical psalter. ${ }^{11}$ In a sense, by using so many Tate and Brady psalms, Colenso was looking back in time culturally, because by the 1860s the "New Version" was in rapid decline and had all but lost the prominence it had enjoyed for the previous 200 years. Sixteen of the metrical psalms are by Isaac Watts (1674-1748). A further nine Watts hymns and scripture paraphrases were included. While the cultural and political antipathy surrounding non-Conformism in England was gradually abating in the second half of the nineteenth century, in Anglican circles it would probably have been taboo for $16 \%$ of a new psalm and hymn collection to be represented by such a prominent and non-Conformist hymn writer. However, none of Colenso's antagonists makes mention of the number of texts by individual authors. Interestingly, Colenso was not beyond including metrical versions of the psalms by John Keble (1792-1866). Keble had argued for the comprehensive nature of HAM but, as one of the leaders of the Tractarian movement, he was also one of Colenso's opponents. ${ }^{12}$ That Colenso was willing to consider Keble's work, perhaps suggests his tolerance for the creative work of personalities who were ideologically poles apart from him. Along with the 92 metrical and paraphrased psalms, there are two additional hymns which are metrical versions of Old Testament scriptures (both from Isaiah). Thus, almost two thirds of the collection is based on material directly from the Old Testament. In contrast, the first edition of HAM only contained six metrical psalms alongside its 267 hymns.

The selection of hymns represents quite a wide variety of perspectives. Authors include John and Charles Wesley; Thomas Ken; James Montgomery; William Cowper; William Williams; Reginald Heber; Henry Lyte; Philip Doddridge; and two translations of

11 In English parishes before the 1820s, metrical psalmody reigned without rival. Two collections of these psalms dominated the English market from the mid-1560s to the early 1800s. They were Sternhold and Hopkins's 1562 collection (also called the "Old Version") and Tate and Brady's revision of 1696 (called the "New Version"). After Tate and Brady's version had been published, the two existed in tandem for many years, some congregations preferring the familiarity of the Old Version-progressives the freshness of the New. For a historical introduction to both the Old and New Versions see Routley (2005), chapter 2.

12 Keble died on 29 March 1866, and many not have heard about Colenso's collection of Psalms and Hymns. 


\section{Bethke}

ancient Latin hymns, of which one was a translation by John Henry Newman (another surprise, given that Newman as a Tractarian leader, along with Keble and Pusey, would have been antagonistic towards him). One of Colenso's criteria for selecting hymns was that they should be appropriate for corporate worship: it seems that by this he meant that the pronouns should be plural ("us" rather than "me"). Thus, the majority of the texts in the collection address or are representative of a group of singers. In the 11 texts which originally were written as personal prayers, he changed singular pronouns to plural. For example, "Guide us, O thou, great Jehovah" which is usually, "Guide me ..." ${ }^{\prime 3}$ However, in three examples he retained some or all of the singular pronouns. ${ }^{14}$ The reason for this is not clear.

In terms of theology, the collection displays numerous modifications of the original texts in order to iron out what Colenso considered the direct worship of Christ, or prayers offered in his name. He seems to have understood the lesser doxology (Glory to the Father, and to the Son, and to the Holy Spirit ...) as being worship of each distinct person of the Trinity, and thus of Christ individually. As a result, he tended to leave out the doxology verses of psalms and hymns. For example, the doxology which is usually included at the end of "All people that on earth do dwell" was omitted. However, in "We praise, we worship Thee, O God" (a fourth century hymn, translated by an anonymous author), Colenso removed the original doxology, which usually appears with this hymn, and replaced it with Thomas Ken's doxology "Praise God from whom all blessings flow." In the last line of this doxology the words "Praise Father, Son and Holy Ghost" appear. One wonders why Colenso omitted doxologies for other psalms and hymns, but inserted this particular version here. Perhaps it was because the greater thrust of this particular version of the doxology is directed to God, with the Son and the Holy Spirit only explicitly appearing towards the end. The hymn in question, as a whole, is directed very clearly to God the Father, and also mentions the angel hosts, which is perhaps why this doxology was acceptable - it too mentions the angels.

In terms of prayer offered to Christ, several textual changes were made. For example, in Wesley's hymn "Let saints below in concert sing" the first line of the fourth verse in the original reads, "Jesu, be thou our constant guide." Colenso appears to have interpreted this as a prayer to Christ, in that Jesus is implored to guide the singer. $\mathrm{He}$ changed the line to, "O God! Be thou our constant guide" so that the prayer is implicitly addressed directly to God the Father. Another example of this type of change is in Ambrose's hymn (translated by Newman) "Now that the sun is gleaming bright." The third verse usually reads, "And while the hours in order flow, / O Christ, securely fence / Our gates, beleaguered by the foe, / The gate of every sense." Colenso interpreted this as a prayer directed to Christ. He solved the problem by replacing "Christ" with "God": "O God, securely fence ..."

13 See Colenso (1866), numbers 52, 53, 82, 91, 95, 97, 99, 108, 114, 116 and 130.

14 See Colenso (1866), numbers 31, 65 and 142. 
There are two other interesting changes which deserve mention, even though they are not directly related to Christology. The first is that Colenso felt that God was, above all, a being of love (see, for example, Colenso 1868a, 130-131). In his selection of psalms and hymns, he purposively removed verses which portrayed God as angry and vengeful. For example, in Watt's paraphrase of Psalm 103, the following verse occurs in the original: "God will not always chide; / And when His strokes are felt, / His strokes are fewer than our crimes, / And lighter than our guilt." Here God is pictured as angry (chiding) and it says that he punishes by metaphorical "strokes." It is likely that such a picture was not consistent with Colenso's teachings, and as a consequence he removed it. A slightly different example of this tenet is in Montgomery's hymn "Stand up and bless the Lord." In the fourth verse the original reads, "... then be His love in Christ proclaimed" (i.e., God's love is displayed through the life of Christ). Colenso changed this to "... then be His [God's] love and truth proclaimed." Here Colenso seems to point to God as the originator of love, rather than Christ as a transmitter of it, i.e., the origin of the love is more clearly highlighted in Colenso's revision.

The second point of interest is the words "tribe" and "tribes." In the Tate and Brady psalm "O God, my heart is fully bent" the second verse usually begins "To all the list'ning tribes, O Lord." Colenso changed this to, "To all the listening world, O Lord." Did he consider the word "tribe" in this context too exclusive? Or was he directing the hymn away from a patriarchal vision of the "tribes" as heathen, and the civilised West as "saved"? By using the word "world" he addressed everybody, not just those considered tribal or uncivilised. In the hymn "Sing to the Lord in joyful strains" the second verse usually reads, "And let the scattered villages / the cheerful notes prolong." He changed this to "And let the distant tribes of earth ..." Was Colenso trying to reference his own mission work, where a distant tribe (the Zulus) were singing Christian praise? Whatever the answer, it is interesting that in one example the word is replaced, while in the other it is inserted.

Given Colenso's antipathy towards HAM, it is interesting that 18 texts in his 1866 edition also appear in HAM. Perhaps this was inevitable, given the general popularity of some psalms and hymns, but it also suggests that Colenso did not reject everything about HAM, only those aspects that did not accord with his teachings.

\section{Reaction to Psalms and Hymns}

Colenso's Psalms and Hymns was published on 8 March 1866. It seems that it was already being used by the congregation at St Peter's Cathedral during that same month, and certainly by the time Colenso preached his sermon on Prayers to Christ on 8 April, in which he refers to the congregation using the book (see Colenso 1868a, 151). However, Colenso's views on HAM were obviously known before Psalms and Hymns was published. A letter from Eustace W. Jacob written from Karkloof parsonage and dated 10 March, appeared in The Natal Witness on 13 March, defending HAM: 


\section{Bethke}

Sir,- - Seeing that no one has stood up in defense of that collection of hymns called "Ancient and Modern" which has been noticed unfavorably by Bishop Colenso, allow me to say that this collection is now in use in most churches in England, and that the Home Government have issued orders that this collection is, for the future, to be bound up with the Prayerbooks issued to men in the army, and to sailors in the Royal navy. I consider that no further testimony to the value of this collection, which was made by a committee of English clergymen, including Bishop Twells, can possibly be required by the most fastidious hymnologist. (The Natal Witness 1866)

Jacob does not mention that the "English clergymen" who assembled HAM were either Tractarians, ritualists of high churchmen. While it is true that some clergy in Natal at the time would have welcomed a move towards ritualistic worship, James Green (18211906) ${ }^{15}$ and John Lake Crompton (1815-1889) ${ }^{16}$ being foremost among them, there were other congregations for whom such worship was scandalous. St Paul's in Durban was an example. Jacob's defence of HAM does not rest on theological matters, but simply on authority; two types of authority, namely the English government and the English clergy. If the government saw fit to include HAM in their general issuing of prayer books, and if English clergymen had compiled the collection, it was satisfactory for general use. Jacobs seems not to have noticed that it was not the collection itself which Colenso was attacking, but some of the theological inferences which a number of the hymns made. He also seems to have missed the point that HAM was a battle ground for episcopal oversight in Natal: Gray representing the orthodox party; ${ }^{17}$ Colenso the liberal vanguard.

A far more critical letter relating to Colenso's new collection was published in The Natal Witness on 26 March 1866. Clearly the author, writing anonymously as "Observer," had carefully studied Colenso's compilation published for the colonies and the 1866 collection. The letter is too lengthy to quote in its entirety, but a summary will suffice. In the first section, "Observer" notes that there are no psalms or hymns in the collection which contain the name "Jesus" or "Christ." He/she goes on to show some of the places where Colenso had edited out these names and replaced them with more generalised designations of God. He/she also indicates where verses seem to have been deliberately left out because they contain a strong Christological ethos. "Observer" was quite meticulous in this regard, because he/she included 10 such examples. He/she completed the section saying, "... surely no more is needed to convince the most prejudiced reader

15 James Green was recruited by Bishop Robert Gray to accompany him to South Africa in 1848 . He was eventually appointed Dean of the newly created Diocese of Natal in 1854 and was to become a thorn in Bishop John Colenso's side. Green became increasingly ritualistic throughout his ministry. See Chapter 12 in Darby (1977).

16 Crompton had been trained in several ritualist parishes in London. He immigrated to Natal in 1857 to improve his ailing health (Darby 1977, 193).

17 Just how orthodox Green and Compton were in terms of Anglicanism is very much debatable. 
that the absence of the sacred name is not the result of accident, but of careful study [italics original]" (The Natal Witness 1866).

"Observer" was correct. The names "Jesus" and "Christ" did not appear. However, there are numerous hymns which directly imply the second person of the Trinity. For example, the doxology discussed above includes "Son." Another example is the hymn "Lord, whom winds and sea obey." This first line is a direct reference to Jesus' calming of the storm on the Lake of Galilee. There are several other examples like this. Yet, "Observer" has a point: it does seem that a thorough study of the metrical psalms and hymns had been made and that deliberate decisions were taken to omit or replace the names "Jesus" or "Christ."

The second part of the letter is much more sarcastic in tone, appealing to the reader's common sense by asking several rhetorical questions about the coherence of Colenso's collection. The essence of this section is to imply that certain aspects of the Christian year cannot be celebrated without hymns mentioning Christ, or that certain essential seasons have been left out. For example, "Observer" notes that the Ascension, which he/she considers "the crowning act of man's redemption" (The Natal Witness 1866), has been omitted. However, it seems that "Observer" is not entirely familiar with Colenso's thoughts about redemption, nor of his Christology. He/she is simply intent on belittling Colenso and his honest grappling with issues of faith.

The closing section of the letter uses the first and second parts as evidence to suggest that Colenso has "ceased to be even a professing Christian [italics original]"; that having a collection of psalms and hymns which does not include prayers to Christ is a "solemn farce" when the prayerbook offers every prayer in the name of Christ; and that by leaving out specific mention of Christ's suffering and death on Good Friday, he dismisses the salvific effect of Jesus' death (The Natal Witness 1866). "Observer" has misunderstood Colenso's thought pattern, though. For example, for Colenso the issue was not about offering prayers in the name of Christ, but directing the prayers to Christ. The formula at the end of many a collect, "through Christ our Lord" is not offensive as long as the opening of the prayer is directed to God (as most are). The second, more important point, is that Colenso did not accept the transactional atonement theory which was common at the time. He felt that a loving God could not and would not require a perfect offering of Christ's self in order to blot out human sin. Colenso's reasoning was that if God was willing to save humankind, why require a sacrifice to enable such an act of grace? In essence, "Observer" appeals to a substitutionist theology, while Colenso accepted a universalist one. Everything relating to one's interpretation of Christ's work on earth revolved around these worldviews. Neither pole of this theological spectrum would have been able to agree on a common interpretation, hence the claim that Colenso had ceased to be a Christian. However, Christianity does not rest on theologies of salvation alone. Colenso's worldview was not new in the thrust of Christian history, just as it is not today. 


\section{Bethke}

The effect of the letter may well have been shattering to some readers: it dismantles the collection and questions its very validity for Christian worship. But it goes further, it also questions the validity of Colenso's Christian convictions. Colenso was clearly hurt by the letter, and sought to defend himself in the sermon entitled "Prayer to Christ" preached on 8 April 1866, and later published in the third volume of Natal Sermons (Colenso1868a).

As it turned out, Colenso was not the only one to react to "Observer's" letter. On 5 April a letter from "A" (who sided with "Observer") appeared in The Natal Witness. "A" agreed that neither "Jesus" nor "Christ" appeared in Colenso's collection, and that anybody who accepted this kind of defective message needed to be warned (The Natal Witness 1866, 8 April 1866). A week later in the same newspaper, a Colenso supporter, "B" challenged "A" to reconsider his/her assumptions about Colenso's theologies, particularly in light of the sermons preached at St Peter's Cathedral that very Sunday. "B" appealed to the fact that "Saviour" appears numerous times in the collection, as does "Word": a direct allusion to Christ from John's Gospel, and pointed out that the majority of items are psalms which do not mention Christ in any case (The Natal Witness 1866).

The letters (Appendix 2) simply indicate what I pointed out earlier, namely that two worldviews were on a collision course, and that it was inevitable that they would find fault with each other.

The furore did not die a quiet death in the colonies. It fired a flame in England where Colenso's views on prayer to and the worship of Christ were shunted around the press (Cox 1888, 100-104). One of the most comprehensive and polarised commentaries was published in The Church Times in October 1866. Though framed as a review (Appendix 3 ) of Colenso's psalm and hymn collections, this review is undoubtedly polemic. The first paragraph makes this clear when it paints Colenso and his supporters as "unscrupulous" while Bishop Gray is portrayed as the righteous upholder of orthodoxy (The Church Times 1866).

The review purports to examine Colenso's psalm and hymn collections mentioned, but while it does offer brief comments about the first collection, it concentrates a great deal more on the 1866 compilation. From the outset, Colenso is accused of holding an ultraSocinian theological stance (The Church Times 1866, 326), namely that he rejected the idea of the pre-existent Logos of John's Gospel, and possibly the doctrine of the Trinity. Such an accusation is strange, given that "Word" (Logos) is one of the substitutes Colenso used in place of "Christ." Early on, the reviewer suggests that besides two or three hymns, there is not "any tenet which a Jew, a Unitarian, or for that matter, a Mohammedan might not accept" (The Church Times 1866, 326). Later he/she says: "It is not merely that he has excluded hymns to Christ from the book, but hymn about Christ. There is nothing like - no, not in the faintest comparison possible-as much about Him in Dr Colenso's hymnal as there is about the Blessed Virgin in an ordinary 


\section{Bethke}

Dissenting book of sacred song" (The Church Times 1866, 326). It is debatable whether Jews or Muslims would have been content to sing about the "Word" and indeed, Unitarians may have found this difficult to stomach too. Nevertheless, the tone here is characteristic of the review as a whole. Although the unnamed reviewer does provide evidence for the strong accusations he/she makes, it is certainly not conclusive. In many ways, this review bears a remarkable likeness to the argument in "Observer's" letter discussed above; the only significant difference being that Colenso's "heresy" is actually named.

Colenso did not take the criticism lightly. Indeed, in 1867 he revised the original collection, adding a further 48 texts. Among these he included several hymns which use both "Jesus" and "Christ." For example: "Jesus Christ is risen today" and "Since Christ our Passover is slain." As before, he modified hymns with singular pronouns to plural ("Sun of our souls, Thou Saviour dear" is an example). Nevertheless, while he introduced certain texts where Christ was mentioned, he still did not allow examples where Christ was openly worshipped to go unchanged. The most notable example is the first verse of a well-known Charles Wesley hymn. The original text reads, "Christ, whose glory fills the skies / Christ, the true and only light." Colenso's version is: "Thou, whose glory fills the skies, / Thou, the true and only light." A singer might assume the "Thou" referred to Christ, but it could equally refer only to God.

The furore in the press did eventually simmer down, but the dent to Colenso's reputation had a lasting effect in the long term. The revised versions of the collection were used at St Peter's Cathedral for at least a decade, probably until Colenso's death, and perhaps a short while afterwards. However, it did not receive further press coverage until Colenso's biography, written by Cox, was published in 1888 .

John Owen reviewed the biography in the 10 March edition of The Academy ${ }^{18}$ (1888, 161-162) ${ }^{19}$ A week later (17 March 1888), in what appears to be something of an attempt to undermine Colenso's story, as told by Cox and reviewed by Owen, The Academy (189) published a letter by Richard Littledale, highlighting Colenso's Psalms and Hymns with specific reference to the absence of Christ and of the doctrine of the Trinity, in which he says that Colenso "rigidly excluded" mention of Christ (189). He also says that the collection was suppressed (189). This letter sparked a robust conversation between Littledale, Owen and Cox that lasted until into April 1888.

A week after Littledale's original letter had been published (24 March 1888), Owen suggested that the mention of Christ is not absolutely necessary for something to be

18 The Academy was an English journal, popular in the nineteenth century, which focused on literature and general topics. At the time that the correspondence discussed in this article was published, the journal included reviews on religious, scientific, historical and literary material.

19 The Academy. Accessed January 21, 2021). https://archive.org/details/TheAcademy_201801. 


\section{Bethke}

Christological in character. As an example, he mentioned that the book of Esther does not mention God, and yet it is still included in the canon (The Academy 1888, 206).

The following week (31 March 1888), Littledale corrected himself, having once again examined the collection, finding that there were allusions to Christ and that the Trinity was, in fact, included (The Academy 1888, 223). He ended his letter stating that "altogether the book exhibits marked and wide departure from precedent, connoting equally wide departure from the usual Anglican standards" (The Academy 1888, 223). This is not strictly true. Before the advent of regular hymn singing in Anglican churches, metrical psalms had been the standard. Psalms would have been sung at Christmas, Easter, Pentecost and so forth-thus no specific mention of Christ was likely. It is probable that Littledale was only right in terms of hymnals in high church, Tractarian and ritualists Anglicanism.

Cox joined the debate on 31 March. He countered several of Littledale's assertions. Firstly, he tried to establish Colenso's motives for creating the psalm and hymn collection. For this he quotes from one of Colenso's letters, dated 2 April 1866:

... with reference to my new Hymn Book, which, strange to say, I find does not contain the name Jesus or Christ from one end to the other. This was quite unintentional on my part, and has merely arisen from the fact of my having rejected hymn after hymn which contained prayers to Christ, which I do object to on scriptural and apostolical grounds, and others in which the name of Jesus is used familiarly and irreverently. (The Academy $1888,223-224)$

He then counters the accusation that there is no reference to the Trinity. Finally, he notes that the collection was not suppressed, but went through several editions (The Academy $1888,224)$.

Littledale does not seem to have been a person who liked to be countered. Also, in the 31 March edition of The Academy (224), he took Owen to task on several of his assertions, some of which Colenso himself had explicitly dealt with in his Natal Sermons. However, Littledale brought the weekly conversation to an end by pointing out that the real issue "is that the structure of Bishop Colenso's Hymnal suggests that the occurrence of Christ's name in a hymn unfits it for Christian use; for no other plausible reason can be offered for its careful elision from his Hymnal" (The Academy $1888,224)$. In relation to the first edition, one could be tempted to agree with Littledale. However, as Cox pointed out in his letter, subsequent editions did guardedly correct this perception. One is left with the impression that while Littledale was a man of some intelligence, his impetuous rhetoric did not always stand up to interrogation. Perhaps he even resembled Colenso, who was characterised by some as rushing into things without giving due consideration to the implications. Indeed, Colenso had to revise his collection to address some of the problems which had been highlighted so negatively in the press. He may have benefited from showing the collection to somebody outside his immediate circle for commentary before publishing it. Likewise, Littledale may well 


\section{Bethke}

have saved face if he had simply consulted the collection before commenting on it in the national press.

\section{Conclusion}

The thrust of this article is that a relatively small collection of psalms and hymns was the catalyst for a debate centring on different Christian worldviews. On the one side was the orthodox camp, reactively defending their Christological belief, primarily on the basis of the infallibility of scripture and tradition. On the other side was a more liberal camp, which advocated for a new way of examining scripture and doctrine in light of scientific discovery and critical theory. The orthodox side acted out of fear that orthodoxy might somehow crumble if exposed to modern scientific scrutiny. As a result, the reactions against Colenso's teachings were sometimes quite emotional. The liberals acted with uncertainty in some cases, but in others with a sense of bombastic confidence. The consequence was a strong sense of inquiry and scepticism with received teaching. Colenso's psalm and hymn collection is an example of this. The ensuing debate on both sides appears to have been a battle to defend points of view that could not always be propped up by evidence. On Colenso's part, the idea that prayers should not be accorded to Christ, nor that he should be worshipped, was problematic. While he did provide interesting defences of his position from the early church, this did not ultimately expunge those early sources that did unequivocally support the worship of Christ. On the orthodox side, though, appeals to precedent were seldom accurate. Too often they were relying on a history that they imagined was reliable and, to some extent, "Catholic." They regularly seem to have forgotten that the Church of England had a strong Protestant and, at times, Calvinistic ethos. The so-called Anglican precedents were hardly old enough to be conclusive nor decisive. In any case, the whole point of a number of reformers was to question the precedents of received church tradition and recast it within the new scientific dispensation. Neither side emerged as a winner in this confrontation.

\section{References}

\section{Newspapers}

The Academy, Vol. 33, 1888.

The Church Times, Vol. 4, October 1866.

The Natal Witness and Agricultural and Commercial Advertiser, 1866, 8 March, 13 March, 26 March and 8 April.

\section{Books}

Colenso, John William. 1866. Psalms and Hymns for Use in the Cathedral Church of St Peter's, Maritzburg and in the Diocese of Natal. Pietermaritzburg: Davis. 


\section{Bethke}

Colenso, John William. 1867. Psalms and Hymns for Use in the Cathedral Church of St Peter's, Maritzburg and in the Diocese of Natal, 2nd edition. Pietermaritzburg: Davis.

Colenso, John William. 1868a. Natal Sermons: Second Series of Discourses Preached in the Cathedral Church of Saint Peter's, Maritzburg. London: Trübner.

Colenso, John William. 1868b. Psalms and Hymns for Use in the Cathedral Church of St Peter's, Maritzburg and in the Diocese of Natal, 3rd edition. Pietermaritzburg: Davis.

Cox, George William. 1888. The Life of John William Colenso D.D.: Bishop of Natal, vol. 2. London: Ridgeway.

Darby, Ian Douglas. 1977. "Anglican Worship in Victorian Natal.” MA thesis: University of Natal.

Draper, Jonathan (Ed.). 2003. The Eye of the Storm: Bishop John William Colenso and the Crisis of Biblical Inspiration. Pietermaritzburg: Cluster.

Guy, Jeff. 1983. The Heretic: A Study of the Life of John William Colenso 1814-1883. Pietermaritzburg: University of Natal Press.

Hinchliff, Peter. 1964. John William Colenso: Bishop of Natal. London: Nelson.

McCart, Thomas K. 1998. The Matter and Manner of Praise: The Controversial Evolution of Hymnody in the Church of England 1760-1820. Lanham: Scarecrow Press.

Rainbow, Bernarr. 2001. The Choral Revival in the Anglican Church, 1839-1872. Woodbridge: Boydell.

Routley, Eric (Ed. and exp. Paul Richardson). 2005. A Panorama of Christian Hymnody. Chicago: GIA.

Temperley, Nicholas. 1979. The Music of the English Parish Church, vol. 1. Cambridge: Cambridge University Press. 
Bethke

\begin{tabular}{|c|c|c|c|c|c|c|}
\hline & Title & Verses & $\begin{array}{l}\text { Original } \\
\text { author }\end{array}$ & Metre & $\begin{array}{l}\text { Mention of } \\
\text { or allusion } \\
\text { to Christ }\end{array}$ & Psalm \\
\hline 1 & $\begin{array}{l}\text { All people that on earth do } \\
\text { dwell }\end{array}$ & 4 & William Kethe & LM & & $\mathrm{Y}$ \\
\hline 2 & $\begin{array}{l}\text { All praise to Thee, in light } \\
\text { arrayed }\end{array}$ & 4 & Thomas Ken & LM & & \\
\hline 3 & $\begin{array}{l}\text { As pants the hart for cooling } \\
\text { streams }\end{array}$ & 4 & Tate and Brady & CM & & $\mathrm{Y}$ \\
\hline 4 & $\begin{array}{l}\text { Author of Good! To thee we } \\
\text { turn }\end{array}$ & 3 & James Merrick & $\mathrm{CM}$ & & \\
\hline 5 & $\begin{array}{l}\text { Awake, my soul, and with the } \\
\text { sun }\end{array}$ & 6 & Thomas Ken & LM & & \\
\hline 6 & Before Jehovah's awful throne & 4 & Isaac Watts & LM & & \\
\hline 7 & $\begin{array}{l}\text { Blest is the man who stands in } \\
\text { awe }\end{array}$ & 3 & Tate and Brady & LM & & $\mathrm{Y}$ \\
\hline 8 & Call Jehovah thy salvation & 4 & $\begin{array}{l}\text { James } \\
\text { Montgomery }\end{array}$ & 8.7. & & $\mathrm{Y}$ \\
\hline 9 & $\begin{array}{l}\text { Come, sound His praise } \\
\text { abroad }\end{array}$ & 4 & Isaac Watts & SM & & $\mathrm{Y}$ \\
\hline 10 & Father of all and God of Love & 4 & $?$ & $\mathrm{CM}$ & & \\
\hline 11 & $\begin{array}{l}\text { For Thee, O God, our } \\
\text { constant praise }\end{array}$ & 4 & Tate and Brady & LM & & $\mathrm{Y}$ \\
\hline 12 & $\begin{array}{l}\text { Forth in Thy Name, O Lord, } \\
\text { we go }\end{array}$ & 4 & Charles Wesley & LM & Easy yoke & \\
\hline 13 & From Thee, O God of Purity & 4 & Charles Wesley & $\mathrm{CM}$ & & \\
\hline 14 & $\begin{array}{l}\text { Give to our God immortal } \\
\text { praise }\end{array}$ & 4 & Isaac Watts & LM & $\begin{array}{l}\text { He sent His } \\
\text { Word with } \\
\text { power to } \\
\text { save (vs 2) }\end{array}$ & $\mathrm{Y}$ \\
\hline 15 & $\begin{array}{l}\text { Give to the Lord with one } \\
\text { acclaim }\end{array}$ & 4 & $?$ & LM & & $\mathrm{Y}$ \\
\hline 16 & $\begin{array}{l}\text { Glory to Thee, my God, this } \\
\text { night }\end{array}$ & 4 & Thomas Ken & LM & $\begin{array}{l}\text { Forgive me, } \\
\text { Lord, for } \\
\text { Thy dear } \\
\text { Son }\end{array}$ & \\
\hline 17 & $\begin{array}{l}\text { God in time of trouble hear } \\
\text { thee }\end{array}$ & 4 & $?$ & 8.7. & & $\mathrm{Y}$ \\
\hline 18 & God is the refuge of His saints & 4 & Isaac Watts & LM & $\begin{array}{l}\text { This sacred } \\
\text { stream, Thy } \\
\text { Living } \\
\text { Word }\end{array}$ & $\mathrm{Y}$ \\
\hline 19 & $\begin{array}{l}\text { God of the morning, at whose } \\
\text { voice }\end{array}$ & 4 & Isaac Watts & LM & & \\
\hline 20 & $\begin{array}{l}\text { God moves in a mysterious } \\
\text { way }\end{array}$ & 5 & $\begin{array}{l}\text { William } \\
\text { Cowper }\end{array}$ & $\mathrm{CM}$ & & \\
\hline 21 & God save our gracious queen! & 2 & $\begin{array}{l}\text { British national } \\
\text { anthem }\end{array}$ & PM & & \\
\hline 22 & $\begin{array}{l}\text { God's perfect law converts the } \\
\text { soul }\end{array}$ & 4 & $?$ & $\mathrm{CM}$ & & $\mathrm{Y}$ \\
\hline
\end{tabular}


Bethke

\begin{tabular}{|c|c|c|c|c|c|c|}
\hline & Title & Verses & $\begin{array}{l}\text { Original } \\
\text { author }\end{array}$ & Metre & $\begin{array}{l}\text { Mention of } \\
\text { or allusion } \\
\text { to Christ }\end{array}$ & Psalm \\
\hline 23 & $\begin{array}{l}\text { Guide us, } \mathrm{O} \text { thou, great } \\
\text { Jehovah }\end{array}$ & 3 & $\begin{array}{l}\text { William } \\
\text { Williams }\end{array}$ & PM & & \\
\hline 24 & Great is the Lord our God & 4 & Isaac Watts & SM & & $\mathrm{Y}$ \\
\hline 25 & $\begin{array}{l}\text { Happy the man whose hopes } \\
\text { rely }\end{array}$ & 4 & Isaac Watts & $6 s$ & & $\mathrm{Y}$ \\
\hline 26 & Have mercy, Lord, on me & 5 & Tate and Brady & SM & & $\mathrm{Y}$ \\
\hline 27 & $\begin{array}{l}\text { Heaven declares its Maker's } \\
\text { glory }\end{array}$ & 6 & $?$ & 8.7 & & $\mathrm{Y}$ \\
\hline 28 & $\begin{array}{l}\text { Holy and reverend is the } \\
\text { Name }\end{array}$ & 4 & John Needham & $\mathrm{CM}$ & & \\
\hline 29 & $\begin{array}{l}\text { Holy, holy, holy, Lord God } \\
\text { Almighty }\end{array}$ & 4 & Reginald Heber & PM & Trinitarian & \\
\hline 30 & How beauteous are their feet & 4 & Isaac Watts & SM & & \\
\hline 31 & $\begin{array}{l}\text { How blest are they, who } \\
\text { always keep }\end{array}$ & 4 & $?$ & $\mathrm{CM}$ & & $\mathrm{Y}$ \\
\hline 32 & $\begin{array}{l}\text { How blest is he, who ne'er } \\
\text { consents }\end{array}$ & 4 & Tate and Brady & $\mathrm{CM}$ & & $\mathrm{Y}$ \\
\hline 33 & $\begin{array}{l}\text { How did my heart rejoice to } \\
\text { hear }\end{array}$ & 4 & Isaac Watts & $\mathrm{CM}$ & & $\mathrm{Y}$ \\
\hline 34 & $\begin{array}{l}\text { How good and pleasant it } \\
\text { must be }\end{array}$ & 4 & Tate and Brady & $\mathrm{CM}$ & & $\mathrm{Y}$ \\
\hline 35 & $\begin{array}{l}\text { How shall the young preserve } \\
\text { their ways }\end{array}$ & 4 & Tate and Brady & $\mathrm{CM}$ & & $\mathrm{Y}$ \\
\hline 36 & $\begin{array}{l}\text { How strange Thy works! How } \\
\text { great thy skill }\end{array}$ & 5 & Isaac Watts & LM & & $\mathrm{Y}$ \\
\hline 37 & $\begin{array}{l}\text { How vain the wisdom of the } \\
\text { wise }\end{array}$ & 4 & Isaac Watts & $\mathrm{CM}$ & & $\mathrm{Y}$ \\
\hline 38 & I lift mine eyes to thine abode & 4 & $?$ & $\mathrm{CM}$ & & $\mathrm{Y}$ \\
\hline 39 & In mercy, not in wrath & 4 & $?$ & SM & & $\mathrm{Y}$ \\
\hline 40 & I waited meekly for the Lord & 4 & Tate and Brady & LM & & $\mathrm{Y}$ \\
\hline 41 & $\begin{array}{l}\text { Jehovah reigns! Let all the } \\
\text { earth }\end{array}$ & 4 & Tate and Brady & LM & & $\mathrm{Y}$ \\
\hline 42 & $\begin{array}{l}\text { Let all the just to God with } \\
\text { joy }\end{array}$ & 4 & Tate and Brady & $\mathrm{CM}$ & & $\mathrm{Y}$ \\
\hline 43 & $\begin{array}{l}\text { Let all the lands with shouts } \\
\text { of joy }\end{array}$ & 4 & Tate and Brady & $\mathrm{CM}$ & & $\mathrm{Y}$ \\
\hline 44 & $\begin{array}{l}\text { Let saints below in concert } \\
\text { sing }\end{array}$ & 4 & Charles Wesley & $\mathrm{CM}$ & & \\
\hline 45 & Let us, with a gladsome mind & 4 & John Milton & $7 \mathrm{~s}$ & & $\mathrm{Y}$ \\
\hline 46 & $\begin{array}{l}\text { Lift up your heads, eternal } \\
\text { gates }\end{array}$ & 4 & Tate and Brady & $\mathrm{CM}$ & & $\mathrm{Y}$ \\
\hline 47 & Lift your eyes of faith and see & 5 & Wesley & $7 \mathrm{~s}$ & & \\
\hline 48 & Lo! God is here! Let us adore & 3 & $\begin{array}{l}\text { John Wesley } \\
\text { (translator) }\end{array}$ & $8 \mathrm{~s}$ & & \\
\hline
\end{tabular}


Bethke

\begin{tabular}{|c|c|c|c|c|c|c|}
\hline & Title & Verses & $\begin{array}{l}\text { Original } \\
\text { author }\end{array}$ & Metre & $\begin{array}{l}\text { Mention of } \\
\text { or allusion } \\
\text { to Christ }\end{array}$ & Psalm \\
\hline 49 & $\begin{array}{l}\text { Lord, at thy word the constant } \\
\text { sun }\end{array}$ & 3 & $\begin{array}{l}\text { Dorothy } \\
\text { Gurney }\end{array}$ & $8 \mathrm{~s}$ & & \\
\hline 50 & $\begin{array}{l}\text { Lord, hear my prayer, and to } \\
\text { my cry }\end{array}$ & 4 & $?$ & $\mathrm{CM}$ & & $\mathrm{Y}$ \\
\hline 51 & $\begin{array}{l}\text { Lord, in the morning Thou } \\
\text { shalt hear }\end{array}$ & 4 & Isaac Watts & $\mathrm{CM}$ & & $\mathrm{Y}$ \\
\hline 52 & $\begin{array}{l}\text { Lord, it belongs not to our } \\
\text { care }\end{array}$ & 4 & Richard Baxter & $\mathrm{CM}$ & $\begin{array}{l}\text { Come, Lord, } \\
\text { when grace } \\
\text { has made us } \\
\text { meet } \\
\text { (Christ) }\end{array}$ & \\
\hline 53 & $\begin{array}{l}\text { Lord, let us know our term of } \\
\text { days }\end{array}$ & 4 & Tate and Brady & $\mathrm{CM}$ & & $\mathrm{Y}$ \\
\hline 54 & $\begin{array}{l}\text { Lord, look on those } \\
\text { assembled here }\end{array}$ & 4 & Joseph Hart & $\mathrm{CM}$ & & \\
\hline 55 & Lord of the mighty main & 4 & $?$ & SM & & \\
\hline 56 & $\begin{array}{l}\text { Lord when we bend before } \\
\text { Thy throne }\end{array}$ & 4 & Joseph Carlyle & $\mathrm{CM}$ & & \\
\hline 57 & $\begin{array}{l}\text { Lord, whom winds and seas } \\
\text { obey }\end{array}$ & 4 & Charles Wesley & $7 \mathrm{~s}$ & $\begin{array}{l}\text { Lord, whom } \\
\text { winds and } \\
\text { sees obey } \\
\text { (Christ) }\end{array}$ & \\
\hline 58 & $\begin{array}{l}\text { May we throughout this day } \\
\text { of thine }\end{array}$ & 2 & Charles Wesley & $\mathrm{CM}$ & Pentecost & \\
\hline 59 & Meet and right it is to sing & 2 & Charles Wesley & PM & Trinitarian & \\
\hline 60 & $\begin{array}{l}\text { My soul, inspired by sacred } \\
\text { love }\end{array}$ & 4 & Tate and Brady & LM & & $\mathrm{Y}$ \\
\hline 61 & My soul, repeat His praise & 6 & Isaac Watts & SM & & $\mathrm{Y}$ \\
\hline 62 & My soul with patience waits & 4 & Tate and Brady & SM & & $\mathrm{Y}$ \\
\hline 63 & My spirit on Thy care & 4 & Henry Lyte & SM & & $\mathrm{Y}$ \\
\hline 64 & $\begin{array}{l}\text { New every morning is the } \\
\text { Love }\end{array}$ & 6 & John Keble & LM & & \\
\hline 65 & $\begin{array}{l}\text { No change of times will ever } \\
\text { shock }\end{array}$ & 4 & Tate and Brady & LM & & $\mathrm{Y}$ \\
\hline 66 & $\begin{array}{l}\text { Now that the sun is gleaming } \\
\text { bright }\end{array}$ & 4 & $\begin{array}{l}\text { Ambrose, } \\
\text { trans. John } \\
\text { Henry } \\
\text { Newman }\end{array}$ & $\mathrm{CM}$ & $\begin{array}{l}\text { That He, the } \\
\text { uncreated } \\
\text { Light } \\
\text { (Nicene } \\
\text { Creed) }\end{array}$ & \\
\hline 67 & $\begin{array}{l}\mathrm{O} \text { all ye nations, praise the } \\
\text { Lord }\end{array}$ & 2 & $?$ & $\mathrm{CM}$ & & $\mathrm{Y}$ \\
\hline 68 & $\begin{array}{l}\text { O all ye people, clap your } \\
\text { hands }\end{array}$ & 4 & Tate and Brady & LM & & $\mathrm{Y}$ \\
\hline 69 & $\begin{array}{l}\text { O come, loud anthems let us } \\
\text { sing }\end{array}$ & 4 & Tate and Brady & LM & & $\mathrm{Y}$ \\
\hline
\end{tabular}


Bethke

\begin{tabular}{|c|c|c|c|c|c|c|}
\hline & Title & Verses & $\begin{array}{l}\text { Original } \\
\text { author }\end{array}$ & Metre & $\begin{array}{l}\text { Mention of } \\
\text { or allusion } \\
\text { to Christ }\end{array}$ & Psalm \\
\hline 70 & $\begin{array}{l}\text { O God, my gracious God, to } \\
\text { Thee }\end{array}$ & 3 & Tate and Brady & $8 \mathrm{~s}$ & & $\mathrm{Y}$ \\
\hline 71 & $\begin{array}{l}\text { O God, my heart is fixed, 'tis } \\
\text { bent }\end{array}$ & 4 & Tate and Brady & LM & & $\mathrm{Y}$ \\
\hline 72 & O God, my heart is fully bent & 4 & Tate and Brady & $\mathrm{CM}$ & & $\mathrm{Y}$ \\
\hline 73 & $\begin{array}{l}\text { O God of Hosts, the mighty } \\
\text { Lord }\end{array}$ & 4 & Tate and Brady & $\mathrm{CM}$ & & $\mathrm{Y}$ \\
\hline 74 & $\begin{array}{l}\text { O God of Jacob, by whose } \\
\text { hand }\end{array}$ & 4 & $\begin{array}{l}\text { Philip } \\
\text { Doddridge }\end{array}$ & $\mathrm{CM}$ & & \\
\hline 75 & O God, our help in ages past & 6 & Isaac Watts & $\mathrm{CM}$ & & $\mathrm{Y}$ \\
\hline 76 & $\begin{array}{l}\text { O God, the strength of every } \\
\text { heart }\end{array}$ & 4 & $?$ & $\mathrm{CM}$ & & \\
\hline 77 & $\begin{array}{l}\text { O help us, Lord! In all our } \\
\text { need }\end{array}$ & 4 & $\begin{array}{l}\text { Henry Hart } \\
\text { Milman }\end{array}$ & $\mathrm{CM}$ & & \\
\hline 78 & O Holy Lord, to Thee & 3 & $\begin{array}{l}\text { George } \\
\text { Rawson }\end{array}$ & PM & & \\
\hline 79 & $\begin{array}{l}\text { O Lord of hosts, my King, my } \\
\text { God }\end{array}$ & 4 & Tate and Brady & $\mathrm{CM}$ & & $\mathrm{Y}$ \\
\hline 80 & $\begin{array}{l}\text { O Lord of Life, the soul, that } \\
\text { knows }\end{array}$ & 4 & $?$ & $\mathrm{CM}$ & $\begin{array}{l}\text { Clear } \\
\text { allusions to } \\
\text { Christ }\end{array}$ & \\
\hline 81 & $\begin{array}{l}\text { O Lord, Thy mercy, our sure } \\
\text { hope }\end{array}$ & 4 & Tate and Brady & LM & & $\mathrm{Y}$ \\
\hline 82 & $\begin{array}{l}\text { O Lord, turn not from us Thy } \\
\text { face }\end{array}$ & 6 & John Mardley & $\mathrm{CM}$ & & \\
\hline 83 & $\begin{array}{l}\text { O Lord, whate'er Thy Will } \\
\text { denies }\end{array}$ & 3 & $\begin{array}{l}\text { Hudson } \\
\text { Thacher? }\end{array}$ & $\mathrm{CM}$ & & \\
\hline 84 & $\begin{array}{l}\text { O praise the Lord, for } \mathrm{He} \text { is } \\
\text { Good }\end{array}$ & 4 & $?$ & $\mathrm{CM}$ & & $\mathrm{Y}$ \\
\hline 85 & $\begin{array}{l}\text { O praise the Lord in that blest } \\
\text { place }\end{array}$ & 3 & Tate and Brady & LM & & $\mathrm{Y}$ \\
\hline 86 & $\begin{array}{l}\text { O praise ye the Lord! Prepare } \\
\text { your glad voice }\end{array}$ & 4 & Tate and Brady & PM & & $\mathrm{Y}$ \\
\hline 87 & $\begin{array}{l}\text { O render thanks, and bless the } \\
\text { Lord }\end{array}$ & 4 & Tate and Brady & $\mathrm{CM}$ & & $\mathrm{Y}$ \\
\hline 88 & O render thanks to God above & 4 & Tate and Brady & LM & & $\mathrm{Y}$ \\
\hline 89 & $\begin{array}{l}\text { O that the Lord would guide } \\
\text { my ways }\end{array}$ & 6 & Isaac Watts & $\mathrm{CM}$ & & $\mathrm{Y}$ \\
\hline 90 & O Thou that hearest prayer & 4 & $?$ & SM & & \\
\hline 91 & $\begin{array}{l}\text { O Thou, who hearest when } \\
\text { sinners cry }\end{array}$ & 3 & Isaac Watts & LM & & $\mathrm{Y}$ \\
\hline 92 & $\begin{array}{l}\text { O Thou, to whom all } \\
\text { creatures bow }\end{array}$ & 5 & Tate and Brady & $\mathrm{CM}$ & & $\mathrm{Y}$ \\
\hline 93 & $\begin{array}{l}\text { O Thou, who hast at Thy } \\
\text { command }\end{array}$ & 3 & Jane Cotterill & LM & & \\
\hline
\end{tabular}


Bethke

\begin{tabular}{|c|c|c|c|c|c|c|}
\hline & Title & Verses & $\begin{array}{l}\text { Original } \\
\text { author }\end{array}$ & Metre & $\begin{array}{l}\text { Mention of } \\
\text { or allusion } \\
\text { to Christ }\end{array}$ & Psalm \\
\hline 94 & $\begin{array}{l}\text { O Thou, whose throne is hid } \\
\text { from men }\end{array}$ & 4 & $\begin{array}{l}\text { O luce qui } \\
\text { mortalibus, } \\
\text { trans. John } \\
\text { Chandler }\end{array}$ & $\mathrm{CM}$ & Trinitarian & \\
\hline 95 & Our eye hath pined away & 4 & John Keble & SM & & $\mathrm{Y}$ \\
\hline 96 & $\begin{array}{l}\text { Our Father sits on yonder } \\
\text { throne }\end{array}$ & 5 & Thomas Kelly & $\mathrm{CM}$ & & \\
\hline 97 & Our maker and our King & 4 & Anne Steele & SM & & \\
\hline 98 & Our souls, in each alarm & 4 & $?$ & SM & & $\mathrm{Y}$ \\
\hline 99 & $\begin{array}{l}\text { Our souls with grateful } \\
\text { thoughts of love }\end{array}$ & 4 & Tate and Brady & $\mathrm{CM}$ & & $\mathrm{Y}$ \\
\hline 100 & $\begin{array}{l}\text { Out of the depths of self- } \\
\text { despair }\end{array}$ & 3 & $\begin{array}{l}\text { Charles } \\
\text { Wesley? }\end{array}$ & $\mathrm{CM}$ & & \\
\hline 101 & $\begin{array}{l}\text { O worship the King, all } \\
\text { glorious above }\end{array}$ & 6 & Robert Grant & PM & & $\mathrm{Y}$ \\
\hline 102 & Pleasant are Thy courts above & 5 & Henry Lyte & $7 \mathrm{~s}$ & & \\
\hline 103 & $\begin{array}{l}\text { Praise the Lord! Ye heavens } \\
\text { adore Him! }\end{array}$ & 4 & $?$ & 8.7 & & $\mathrm{Y}$ \\
\hline 104 & $\begin{array}{l}\text { Praise ye the Lord! Our God } \\
\text { to praise }\end{array}$ & 4 & Tate and Brady & LM & & $\mathrm{Y}$ \\
\hline 105 & $\begin{array}{l}\text { Praise ye the Lord! 'Tis good } \\
\text { to raise }\end{array}$ & 5 & Isaac Watts & LM & & $\mathrm{Y}$ \\
\hline 106 & Put thou thy trust in God & 4 & $\begin{array}{l}\text { Trans. John } \\
\text { Wesley }\end{array}$ & SM & & \\
\hline 107 & $\begin{array}{l}\text { Raise your voice, and } \\
\text { thankful sing }\end{array}$ & 4 & $?$ & $7 \mathrm{~s}$ & & $\mathrm{Y}$ \\
\hline 108 & $\begin{array}{l}\text { Show pity Lord! O Lord, } \\
\text { forgive }\end{array}$ & 4 & Isaac Watts & LM & & $\mathrm{Y}$ \\
\hline 109 & Sing the song unheard before & 5 & John Keble & $7 \mathrm{~s}$ & & \\
\hline 110 & $\begin{array}{l}\text { Sing to the Lord a new-made } \\
\text { song }\end{array}$ & 4 & Tate and Brady & $\mathrm{CM}$ & & $\mathrm{Y}$ \\
\hline 111 & $\begin{array}{l}\text { Sing to the Lord in joyful } \\
\text { strains }\end{array}$ & 4 & $\begin{array}{l}\text { Pratt's } \\
\text { Collection? }\end{array}$ & $\mathrm{CM}$ & & \\
\hline 112 & Sovereign ruler of the skies & 6 & John Ryland & $7 \mathrm{~s}$ & $\begin{array}{l}\text { Times to } \\
\text { taste a } \\
\text { Saviour's } \\
\text { love } \\
\text { (Jesus?) }\end{array}$ & \\
\hline 113 & Stand up, and bless the Lord & 4 & $\begin{array}{l}\text { James } \\
\text { Montgomery }\end{array}$ & SM & & \\
\hline 114 & $\begin{array}{l}\text { Sweet is the work, O God, our } \\
\text { King }\end{array}$ & 4 & Isaac Watts & LM & & \\
\hline 115 & The Church of God below & 4 & $?$ & SM & & $\mathrm{Y}$ \\
\hline 116 & $\begin{array}{l}\text { The day is gone-yet with the } \\
\text { day }\end{array}$ & 4 & Thomas Ken & LM & & \\
\hline
\end{tabular}


Bethke

\begin{tabular}{|c|c|c|c|c|c|c|}
\hline & Title & Verses & $\begin{array}{l}\text { Original } \\
\text { author }\end{array}$ & Metre & $\begin{array}{l}\text { Mention of } \\
\text { or allusion } \\
\text { to Christ }\end{array}$ & Psalm \\
\hline 117 & Thee we adore, Eternal Name & 4 & Isaac Watts & $\mathrm{CM}$ & & \\
\hline 118 & $\begin{array}{l}\text { The God of gods, Jehovah, } \\
\text { spake }\end{array}$ & 5 & John Keble & 8.7 & & $\mathrm{Y}$ \\
\hline 119 & $\begin{array}{l}\text { The good man's way is God's } \\
\text { delight }\end{array}$ & 3 & Tate and Brady & $8 \mathrm{~s}$ & & $\mathrm{Y}$ \\
\hline 120 & $\begin{array}{l}\text { The heavens declare Thy } \\
\text { glory, Lord }\end{array}$ & 4 & Tate and Brady & $\mathrm{CM}$ & & $\mathrm{Y}$ \\
\hline 121 & $\begin{array}{l}\text { The Lord Himself, the mighty } \\
\text { Lord }\end{array}$ & 4 & Tate and Brady & $\mathrm{CM}$ & & $\mathrm{Y}$ \\
\hline 122 & $\begin{array}{l}\text { The Lord is good! Fresh acts } \\
\text { of grace }\end{array}$ & 4 & Tate and Brady & $\mathrm{CM}$ & & $\mathrm{Y}$ \\
\hline 123 & The Lord Jehovah reigns & 3 & Isaac Watts & 6.6 .8 & & $\mathrm{Y}$ \\
\hline 124 & The Lord of earth and sky & 3 & Charles Wesley & PM & & \\
\hline 125 & $\begin{array}{l}\text { The Lord of Glory is my } \\
\text { Light }\end{array}$ & 4 & $\begin{array}{l}\text { Could be a } \\
\text { paraphrase of } \\
\text { Watts }\end{array}$ & LM & & $\mathrm{Y}$ \\
\hline 126 & There is a land of pure delight & 6 & Isaac Watts & $\mathrm{CM}$ & & \\
\hline 127 & $\begin{array}{l}\text { The star of day hath risen } \\
\text { now! }\end{array}$ & 4 & $\begin{array}{l}\text { Ad pirum } \\
\text { "Church Poetry } \\
\text { or Christian } \\
\text { Thoughts in } \\
\text { Old and } \\
\text { Modern Verse" } \\
\text { Anne Mozley }\end{array}$ & LM & $\begin{array}{l}\text { The Star of } \\
\text { Day hath } \\
\text { risen now } \\
\text { (Christ) }\end{array}$ & \\
\hline 128 & The voice of one that cries & 4 & Henry Alford? & SM & $\begin{array}{l}\text { Foretelling } \\
\text { John the } \\
\text { Baptist }\end{array}$ & \\
\hline 129 & $\begin{array}{l}\text { Thou Lord, by strictest search } \\
\text { has known }\end{array}$ & 4 & Tate and Brady & LM & & $\mathrm{Y}$ \\
\hline 130 & $\begin{array}{l}\text { Thousands of thousands stand } \\
\text { around }\end{array}$ & 5 & John Mason & $\mathrm{CM}$ & & $\mathrm{Y}$ \\
\hline 131 & $\begin{array}{l}\text { Thou, who art enthroned } \\
\text { above }\end{array}$ & 3 & George Sandys & $7 \mathrm{~s}$ & $\begin{array}{l}\text { "Thou in } \\
\text { whom we } \\
\text { live and } \\
\text { move": } \\
\text { allusion to } \\
\text { Christ } \\
\text { through Paul }\end{array}$ & $\mathrm{Y}$ \\
\hline 132 & $\begin{array}{l}\text { Through all the changing } \\
\text { scenes of life }\end{array}$ & 6 & Tate and Brady & $\mathrm{CM}$ & & $\mathrm{Y}$ \\
\hline 133 & $\begin{array}{l}\text { Tis good for us, most gracious } \\
\text { Lord }\end{array}$ & 4 & Tate and Brady & $\mathrm{CM}$ & & $\mathrm{Y}$ \\
\hline 134 & To bless Thy chosen race & 4 & Tate and Brady & SM & & $\mathrm{Y}$ \\
\hline 135 & $\begin{array}{l}\text { To celebrate Thy praise, } \mathrm{O} \\
\text { God }\end{array}$ & 4 & Tate and Brady & $\mathrm{CM}$ & & $\mathrm{Y}$ \\
\hline
\end{tabular}


Bethke

\begin{tabular}{|c|c|c|c|c|c|c|}
\hline \multicolumn{7}{|c|}{$\begin{array}{l}\text { Appendix } 1 \\
\text { List of texts in Colenso's Psalms and Hymns (1866) and its first two revisions (1867 and 1868b) }\end{array}$} \\
\hline & Title & Verses & $\begin{array}{l}\text { Original } \\
\text { author }\end{array}$ & Metre & $\begin{array}{l}\text { Mention of } \\
\text { or allusion } \\
\text { to Christ }\end{array}$ & Psalm \\
\hline 136 & To God, in whom I trust & 4 & Tate and Brady & SM & & $\mathrm{Y}$ \\
\hline 137 & $\begin{array}{l}\text { To God, our never failing } \\
\text { strength }\end{array}$ & 4 & Tate and Brady & $\mathrm{CM}$ & & $\mathrm{Y}$ \\
\hline 138 & To God, the mighty Lord & 4 & Tate and Brady & PM & & $\mathrm{Y}$ \\
\hline 139 & To God, the only wise & 4 & Isaac Watts & SM & & \\
\hline 140 & $\begin{array}{l}\text { To Thee, our God, when } \\
\text { troubles press }\end{array}$ & 4 & $?$ & $\mathrm{CM}$ & & $\mathrm{Y}$ \\
\hline 141 & $\begin{array}{l}\text { Wake, and lift up thyself, my } \\
\text { heart }\end{array}$ & 6 & Thomas Ken & LM & & \\
\hline 142 & $\begin{array}{l}\text { We'll celebrate Thy praises, } \\
\text { Lord }\end{array}$ & 4 & Tate and Brady & $\mathrm{CM}$ & & $\mathrm{Y}$ \\
\hline 143 & $\begin{array}{l}\text { We praise, we worship Thee, } \\
\text { O God! }\end{array}$ & 4 & $\begin{array}{l}\text { Ancient hymn, } \\
\text { English } \\
\text { translation } \\
\text { anonymous }\end{array}$ & LM & $\begin{array}{l}\text { Doxology } \\
\text { (Trinitarian) }\end{array}$ & \\
\hline 144 & When, overwhelmed by grief & 4 & Isaac Watts & SM & & Y \\
\hline 145 & $\begin{array}{l}\text { Whom have we, Lord, in } \\
\text { heaven but Thee }\end{array}$ & 4 & Harriet Auber & $\mathrm{CM}$ & & $\mathrm{Y}$ \\
\hline 146 & $\begin{array}{l}\text { With glory clad, with strength } \\
\text { arrayed }\end{array}$ & 4 & Tate and Brady & LM & & $\mathrm{Y}$ \\
\hline 147 & $\begin{array}{l}\text { With one consent let all the } \\
\text { earth }\end{array}$ & 4 & Tate and Brady & LM & & $\mathrm{Y}$ \\
\hline 148 & Ye bounless realms of joy & 3 & Tate and Brady & PM & & $\mathrm{Y}$ \\
\hline 149 & Ye holy angels bright & 3 & Richard Baxter & PM & & \\
\hline 150 & $\begin{array}{l}\text { Ye saints and servants of the } \\
\text { Lord }\end{array}$ & 2 & Tate and Brady & $6.8 \mathrm{~s}$ & & $\mathrm{Y}$ \\
\hline 151 & Ye servants of the Lord & 4 & $\begin{array}{l}\text { Philip } \\
\text { Doddridge }\end{array}$ & SM & $\begin{array}{l}\text { Allusion to } \\
\text { Christ with } \\
\text { parables } \\
\text { from } \\
\text { Gospels }\end{array}$ & \\
\hline 152 & $\begin{array}{l}\text { You that have spent the silent } \\
\text { night }\end{array}$ & 6 & $\begin{array}{l}\text { George } \\
\text { Gascoigne }\end{array}$ & $\mathrm{CM}$ & & \\
\hline \multicolumn{7}{|c|}{ Additional texts in the 1867 edition } \\
\hline \multicolumn{7}{|c|}{ Hymns from the Prayer Book } \\
\hline 153 & $\begin{array}{l}\text { Come, Holy Ghost! Creator, } \\
\text { come }\end{array}$ & 5 & $\begin{array}{l}\text { Rabanus } \\
\text { Maurus, trans. } \\
\text { Catherine } \\
\text { Winkworth } \\
\end{array}$ & LM & & \\
\hline 154 & $\begin{array}{l}\text { Come, Holy Ghost! Creator, } \\
\text { come }\end{array}$ & 5 & $\begin{array}{l}\text { Rabanus } \\
\text { Maurus, trans. } \\
\text { Anon. }\end{array}$ & $\mathrm{CM}$ & & \\
\hline 155 & $\begin{array}{l}\text { High let us swell our tuneful } \\
\text { notes }\end{array}$ & 4 & $\begin{array}{l}\text { Philip } \\
\text { Doddridge }\end{array}$ & $\mathrm{CM}$ & & \\
\hline
\end{tabular}


Bethke

\begin{tabular}{|c|c|c|c|c|c|c|}
\hline \multicolumn{7}{|c|}{$\begin{array}{l}\text { Appendix } 1 \\
\text { List of texts in Colenso's Psalms and Hymns (1866) and its first two revisions (1867 and 1868b) }\end{array}$} \\
\hline & Title & Verses & $\begin{array}{l}\text { Original } \\
\text { author }\end{array}$ & Metre & $\begin{array}{l}\text { Mention of } \\
\text { or allusion } \\
\text { to Christ }\end{array}$ & Psalm \\
\hline 156 & Hark! The herald angels sing & 4 & Charles Wesley & $7 \mathrm{~s}$ & & \\
\hline 157 & While shepherds watched & 6 & Nahum Tate & CM & & \\
\hline 158 & $\begin{array}{l}\text { Since Christ, our Passover, is } \\
\text { slain }\end{array}$ & 5 & Tate and Brady & $\mathrm{CM}$ & & \\
\hline 159 & Jesus Christ is risen today & 3 & Anon. & $7 \mathrm{~s}$ & & \\
\hline \multicolumn{7}{|c|}{ Additional texts in the 1868 edition } \\
\hline 160 & $\begin{array}{l}\text { Abide with me, fast falls the } \\
\text { eventide }\end{array}$ & 4 & Henry Lyte & PM & & \\
\hline 161 & $\begin{array}{l}\text { Again, the Lord of light and } \\
\text { life }\end{array}$ & 4 & Anna Barbauld & $\mathrm{CM}$ & & \\
\hline 162 & Brief life is here our portion & 4 & $\begin{array}{l}\text { Bernard of } \\
\text { Cluny, trans. } \\
\text { John Mason } \\
\text { Neale }\end{array}$ & 7.6 . & & \\
\hline 163 & Come, all who truly bear & 4 & Charles Wesley & SM & & \\
\hline 164 & $\begin{array}{l}\text { Come, Holy Ghost, Eternal } \\
\text { God }\end{array}$ & 4 & $\begin{array}{l}\text { Rabanus } \\
\text { Maurus, trans. } \\
\text { Anon. }\end{array}$ & CM & & \\
\hline 165 & $\begin{array}{l}\text { Come, Holy Ghost, our souls } \\
\text { inspire }\end{array}$ & 3 & $\begin{array}{l}\text { Rabanus } \\
\text { Maurus, trans. } \\
\text { John Cosin }\end{array}$ & 6.8. & & \\
\hline 166 & $\begin{array}{l}\text { Come, Holy Spirit, heavenly } \\
\text { Dove }\end{array}$ & 4 & Isaac Watts & LM & & \\
\hline 167 & Creator Spirit, by whose aid & 3 & $\begin{array}{l}\text { Rabanus } \\
\text { Maurus, } \\
\text { paraphrased by } \\
\text { John Dryden }\end{array}$ & 6.8. & & \\
\hline 168 & $\begin{array}{l}\text { Father, whatever of heavenly } \\
\text { bliss }\end{array}$ & 3 & Anne Steele & $\mathrm{CM}$ & & \\
\hline 169 & $\begin{array}{l}\text { Forth from the dark and } \\
\text { stormy sky }\end{array}$ & 2 & Reginald Heber & 6.8. & & \\
\hline 170 & $\begin{array}{l}\text { From all that dwell below the } \\
\text { skies }\end{array}$ & 2 & Isaac Watts & LM & & \\
\hline 171 & $\begin{array}{l}\text { From depths of woe I raise to } \\
\text { Thee }\end{array}$ & 3 & $\begin{array}{l}\text { Martin Luther, } \\
\text { trans. Anon. }\end{array}$ & PM & & \\
\hline 172 & $\begin{array}{l}\text { From Greenland's icy } \\
\text { mountains }\end{array}$ & 3 & Reginald Heber & 7.6. & & \\
\hline 173 & $\begin{array}{l}\text { Glorious things of Thee are } \\
\text { spoken }\end{array}$ & 4 & John Newton & 8.7. & & \\
\hline 174 & God of mercy, God of grace & 3 & Henry Lyte & $7 \mathrm{~s}$ & & \\
\hline 175 & $\begin{array}{l}\text { God the Lord a King } \\
\text { remaineth }\end{array}$ & 3 & John Keble & PM & & $\mathrm{Y}$ \\
\hline 176 & $\begin{array}{l}\text { Hark! The glad sound! The } \\
\text { Saviour comes }\end{array}$ & 4 & $\begin{array}{l}\text { Philip } \\
\text { Doddridge }\end{array}$ & $\mathrm{CM}$ & & \\
\hline 177 & $\begin{array}{l}\text { How are Thy servants blest, } \mathrm{O} \\
\text { Lord! }\end{array}$ & 6 & $\begin{array}{l}\text { Joseph } \\
\text { Addison } \\
\end{array}$ & $\mathrm{CM}$ & & \\
\hline
\end{tabular}


Bethke

\begin{tabular}{|c|c|c|c|c|c|c|}
\hline \multicolumn{7}{|c|}{$\begin{array}{l}\text { Appendix } 1 \\
\text { List of texts in Colenso's Psalms and Hymns (1866) and its first two revisions (1867 and } 1868 \mathrm{~b})\end{array}$} \\
\hline & Title & Verses & $\begin{array}{l}\text { Original } \\
\text { author }\end{array}$ & Metre & $\begin{array}{l}\text { Mention of } \\
\text { or allusion } \\
\text { to Christ }\end{array}$ & Psalm \\
\hline 178 & $\begin{array}{l}\text { In token that thou shalt not } \\
\text { fear }\end{array}$ & 5 & Henry Alford & $\mathrm{CM}$ & & \\
\hline 179 & Lord of the worlds above & 3 & Isaac Watts & PM & & \\
\hline 180 & $\begin{array}{l}\text { My shepherd will supply my } \\
\text { need }\end{array}$ & 5 & Isaac Watts & $\mathrm{CM}$ & & $\mathrm{Y}$ \\
\hline 181 & $\begin{array}{l}\text { O God my Father, while I } \\
\text { stray }\end{array}$ & 6 & Charlotte Elliot & PM & & \\
\hline 182 & $\begin{array}{l}\text { O God, Thou art my God } \\
\text { alone }\end{array}$ & 4 & $\begin{array}{l}\text { James } \\
\text { Montgomery }\end{array}$ & LM & & \\
\hline 183 & O Lord and Maker, hear! & 3 & $?$ & PM & & \\
\hline 184 & $\begin{array}{l}\text { O Lord, how happy should we } \\
\text { be }\end{array}$ & 5 & Joseph Anstice & PM & & \\
\hline 185 & O Spirit of the Living God & 4 & Henry Tweedy & LM & & \\
\hline 186 & $\begin{array}{l}\text { Our blest Redeemer, ere he } \\
\text { breathed }\end{array}$ & 5 & Harriet Auber & PM & & \\
\hline 187 & $\begin{array}{l}\text { Praise to God, immortal } \\
\text { praise }\end{array}$ & 4 & Anna Barbauld & $7 \mathrm{~s}$ & & \\
\hline 188 & $\begin{array}{l}\text { Sun of our souls! Thou } \\
\text { Saviour dear }\end{array}$ & 5 & John Keble & LM & & \\
\hline 189 & $\begin{array}{l}\text { Sweet is the memory of Thy } \\
\text { grace }\end{array}$ & 4 & Isaac Watts & $\mathrm{CM}$ & & \\
\hline 190 & Thee we adore, Eternal Name & 4 & Isaac Watts & $\mathrm{CM}$ & & \\
\hline 191 & $\begin{array}{l}\text { The Lord is King! Lift up } \\
\text { your voice }\end{array}$ & 3 & Josiah Conder & LM & & \\
\hline 192 & $\begin{array}{l}\text { The Lord my pasture shall } \\
\text { prepare }\end{array}$ & 3 & $\begin{array}{l}\text { Joseph } \\
\text { Addison } \\
\end{array}$ & 6.8. & & $\mathrm{Y}$ \\
\hline 193 & The Lord my shepherd is & 4 & Isaac Watts & SM & & $\mathrm{Y}$ \\
\hline 194 & $\begin{array}{l}\text { The strain of upraise of joy } \\
\text { and praise }\end{array}$ & $\begin{array}{l}\text { Unusua } \\
1 \text { format }\end{array}$ & $\begin{array}{l}\text { Balbulus } \\
\text { Notker, trans. } \\
\text { John Mason } \\
\text { Neale }\end{array}$ & PM & & \\
\hline 195 & $\begin{array}{l}\text { The spacious firmament on } \\
\text { high }\end{array}$ & 3 & $\begin{array}{l}\text { Joseph } \\
\text { Addison } \\
\end{array}$ & DLM & & \\
\hline 196 & $\begin{array}{l}\text { The sun is set- the day is } \\
\text { gone }\end{array}$ & 4 & $?$ & DLM & & \\
\hline 197 & $\begin{array}{l}\text { Thou God of power and God } \\
\text { of love }\end{array}$ & 2 & John Walker & 8.8 .6 . & & \\
\hline 198 & $\begin{array}{l}\text { Thou, whose glory fills the } \\
\text { skies }\end{array}$ & 3 & Charles Wesley & $6.8 \mathrm{~s}$ & & \\
\hline 199 & $\begin{array}{l}\text { Through the day Thy love has } \\
\text { spared us }\end{array}$ & 2 & Thomas Kelly & $6.8 \mathrm{~s}$ & & \\
\hline \multicolumn{7}{|c|}{ Dismissals } \\
\hline 200 & $\begin{array}{l}\text { Lord dismiss us with Thy } \\
\text { blessing }\end{array}$ & 2 & John Fawcett & PM & & \\
\hline \multicolumn{7}{|c|}{ Doxologies } \\
\hline
\end{tabular}


Bethke

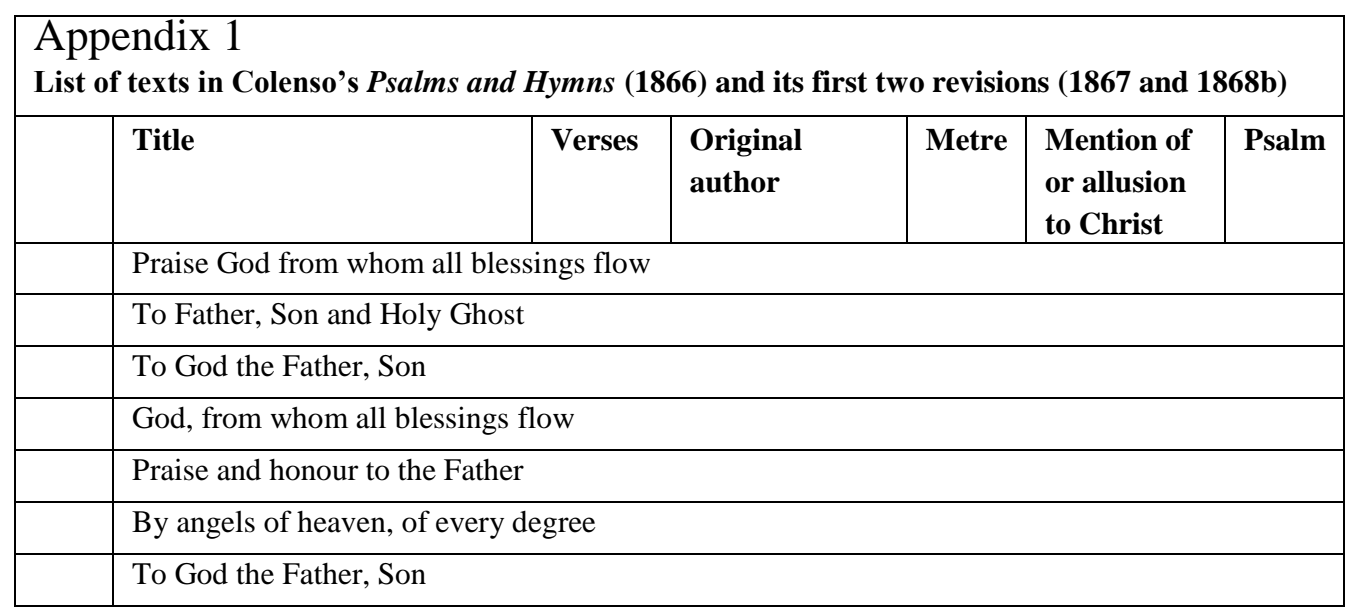


Bethke

\section{Appendix 2}

\section{Letters relating to Hymns Ancient and Modern and Colenso's Psalms and Hymns}

a) Published in The Natal Witness and Agricultural and Commercial Advertiser, Tuesday 13 March 1866.

\section{Karkloof Parsonage, 10 March 1866.}

Sir,- Seeing that no one has stood up in defense of that collection of hymns called "Ancient and Modern" which has been noticed unfavorably by Bishop Colenso, allow me to say that this collection is now in use in most churches in England, and that the Home Government have issued orders that this collection is, for the future, to be bound up with the Prayerbooks issued to men in the army, and to sailors in the Royal navy. I consider that no further testimony to the value of this collection, which was made by a committee of English clergymen, including Bishop Twells, can possibly be required by the most fastidious hymnologist.

I am, \&c.,

Eustace W. Jacob

b) Published in The Natal Witness and Agricultural and Commercial Advertiser, Friday 30 March 1866.

Pietermaritzburg, 26 March, 1866.

\section{To the editor of The Natal Witness.}

Sir,-As many of your readers, I believe, attend the services held by Dr Colenso, and they use, as I suppose, the collection of psalms and hymns recently issued by him, a few facts connected with this collection may be read by some of them with interest, and perhaps not without profit. Without further preface, therefore, I will beg their attention to the following facts:

1. That holy name which is the foundation of every Christian's hope, is never once mentioned. Neither "Jesus" nor "Christ" is to be found from beginning to end of the book!

But some of your readers may say: "It is surely not necessary that either of these names, sacred as they are, and dear to every Christian as they must be, should appear in every hymn; this omission, therefore, may be accidental." Not so. Let the facts speak for themselves. I have carefully compared this collection with that previously published by Dr Colenso, and the following are the results:

In No. 52, last verse, the line:

But 'tis enough, our God knows all,

reads, in the old collection,

But 'tis enough that Christ knows all.

No. 54 has, in the old collection, the following additional verse: 


\section{Bethke}

Whatever be our destined case,

Accept us in Thy Son:

Give us Thy Gospel and Thy Grace,

And then-Thy Will be done.

No. 59 had the following, which is discarded in the new collection:

Father! We Thy mercy praise

Which gave Thy Son to die;

Brightness of Thy Father's face!

Then, too, we glorify.

Holy Comforter Divine

Praise to Thee by all be given,

Till we in full chorus join

And Earth is turned to Heaven.

No 66, third verse:

"O God" is substituted for "O Christ."

In No. 78, first verse, second line:

"O Christ our King" is changed into "O Lord our God."

In No. 91, before the last verse, is omitted:

Though we have grieved Thy Spirit, Lord,

Thy help and comfort still afford;

Behold! We come before Thy Throne, And plead the merits of Thy Son.

In No. 100 the last verse is omitted, which is as follows:

Ye trembling souls, confide in God,

Mercy with Him remains;

And cleansing through a Saviour's Blood

From all your guilty stains.

In No. 113, third verse, third line:

Then be His Love and Truth proclaimed.

is substituted for:

Then be His Love in Christ proclaimed.

In No. 124 is omitted:

Saviour! Thy previous Blood

From God obtained this grace,

Who therefore has bestowed

On us a longer space:

Thou dost on our behalf appear,

And lo! we see another year!

In No. 149, second verse, for: 


\section{Bethke}

Who see your Saviour's face,

we find:

Who see your Maker's face,

And in the same hymn the following verse is omitted altogether:

My soul, bear thou thy part,

Triumph in God above,

And with a well-tuned heart,

Sing thou the songs of love!

Thou art His own, Whose precious Blood,

Shed for thy Good, His Love made known.

More alterations of the same tendency might be adduced, but surely no more is needed to convince the most prejudiced reader that the absence of the sacred name is not the result of accident, but of careful study.

2. I would invite your readers' attention to a few peculiarities in the arrangement of the "hymns suited for special occasions." They may, perhaps be ready to exclaim: "What! arrange hymns, in which Christ is never mentioned, to suit Christmas and Easter? The thing is absurd!" I grant it, Sir, the thing is absurd, as we shall presently see. Not to occupy, however, too much of your space, I will bring but one instance. For Christmas day — on which great festival the Church commemorates the birth of her Lord as a little infant, cradled in a manger, destitute, to all outwards appearance, of any semblance of glory, and even of what we consider the common necessaries, or certainly of the common comforts of life - those who worship under Dr Colenso are advised to sing:

Throned in awful Majesty

Far above all gods, is He!

Could anything be more in-appropriate to the occasion? How different the simple words of the Church of England's Christmas hymn:

With the angelic host proclaim

Christ is born in Bethlehem!

But then the Church of England is not ashamed of, nor eager to dispense with, the name of Christ.

Passing from this, I cannot but notice that this week - in which we celebrate the great sufferings of our Saviour - has not a hymn appointed for it (not even for Good Friday); that Ascension Day, on which we commemorate the crowning act of man's redemption ("I go to prepare a place for you") is utterly ignored; that the two Sacraments of Baptism and the Lord's Supper are unnoticed, while Harvest is remembered.

And now, Sir, I must beg your patience while I make a very few remarks which naturally arise out of the subject before us. 
Is it not a "solemn farce" for Dr Colenso to read, as I presume, he does, week after week, the prayers of the Church of England, which are, without exception, offered in the name of Christ, while he provides for his hearers a collection of hymns from which that holy name, every mention of his meritorious sufferings and death have been carefully omitted, or rather, I should say studiously expunged?

Oh! Let those who have begun to follow such a man, pause a little, and see whither he is leading them. Does not this studied exclusion of the holy name of Christ go a long way towards showing us that Dr Colenso, at least, has ceased to be even a professing Christian? For can a Christian, even if only in profession, ignore the holy name he bears? Having, at his baptism, been "signed with the sign of the cross, in token that hereafter he shall not be ashamed to confess the faith of Christ crucified, but manfully to fight under his banner," we see him now deserting his colours-ignoring the very name of Christ. And shall we follow him, and desert too? We may do so; but if we do, we must do it in the face of this plain declaration: "Whosoever, therefore, shall be ashamed of me, and my words, in this adulterous and sinful generation, of him also shall the Son of Man be ashamed when he cometh in the glory of his Father with the holy angels."

Well may we join in the beautiful prayer for the church militant: "That all they who do confess thy holy name, may agree in the truth of thy holy word," leaving it to those who, as we see, do not confess that holy name, to (as the inevitable consequence) throw doubts upon that truth.

Surely the "Church of England Defence Association" will not remain inactive at this crisis, but will come forward now, when there is such urgent need, and endeavour to defend the members of the Church of England in this colony (such of them, at least as attend Dr Colenso's services) from being deprived of the inestimable privilege of singing the praises of Christ.

I am, Sir, Your obedient servant, Observer.

c) Published in The Natal Witness and Agricultural and Commercial Advertiser, Tuesday 10 April 1866.

To the editor of The Natal Witness, Pietermaritzburg, 5 April 1866.

Sir,- In common with many other churchmen, I have been waiting for a reply to the statements of "Observer" regarding the hymn book prepared by Dr Colenso for the use of his congregation. "Observer" states nothing but a simple matter of fact when he says that "neither 'Jesus' nor 'Christ' is to be found from beginning to end of the book."

What are we to gather from this fact? May we not safely infer another fact, viz., that $\mathrm{Dr}$ Colenso is ashamed to confess the "faith of Christ crucified," when he so carefully expunged that Holy Name from a work professedly compiled to assist a Christian congregation in their devotion? Can we believe that a man who so studiously keeps out of sight the very name of the divine founder of our religion, is, or ought to be, a shepherd 


\section{Bethke}

of Christ's flock? Surely all churchmen, and all Christians, ought to consider these things: wither do they tend, and what do they signify? Do they not point to an utter disbelief in that faith which declares, "there is none other name under heaven whereby a man can be saved?" And may churchmen not see, that if Dr Colenso had the poweras undoubtedly, he has the will — he would wipe out the very name of the Saviour from the services of the church.

These are serious matters, and it behoves all thinking men to ponder well before they follow a leader who knows not whither he may drift - but who is rapidly advancing in a course which must inevitably separate him from all true Christians

I am, Sir, your obedient servant.

A.

d) Published in The Natal Witness and Agricultural and Commercial Advertiser, Friday 20 April 1866.

To the editor of The Natal Witness, 11 April 1866.

Sir,-If "A," who calls himself a "Churchman," had ever listened to a sermon of Bishop Colenso's, he would have known that he does not "keep out of sight the very name of the Divine founder of our religion," and he would not have "borne false witness against his neighbour." If he had been present last Sunday evening in the Cathedral, he would have heard the Bishop preach on the subject to which he refers, and express his views fully, and to my mind most satisfactorily, on the question of Hymns designed for use in public worship, and that in a far more suitable place than in the columns of a newspaper. "A" will probably think it right to procure and peruse a copy of the Bishop's sermon when published. Meanwhile, I will remind him that of the 152 "Psalms and Hymns" in the Cathedral Hymn Book, two-thirds, I believe, are Psalms, which do not, of course, contain the Saviour's name; and I presume he must have seen, as he professes to have inspected the book (though he carefully suppresses the fact) that some of the Hymns expressly do mention the Saviour (e.g., 16 and 141), though not the particular name in question. If he will now refer to the Hymn Book of the Church of Scotland, he will find, I think, that it contains 160 Psalms, 67 Paraphrases of scripture, and five Hymns; that in these last neither of the two names appear, nor in 53 of the Paraphrases; and further, that in not one these 72 compositions is prayer offered to Christ, under any name.

I will add, for "A's" information, that the Bishop reminded us that our Lord himself instructs us "When you pray, to say, our Father:" that he has taught us to pray to the Father in his name, but has never taught us to pray to himself; and that St Paul, though believing entirely in the Divinity of Christ, never makes a prayer to him, but teaches us, by precept and example, "in everything to make our requests known unto God"- - very serious fact for the consideration of those who use the book "Hymns Ancient and Modern" in which almost every other Hymn contains prayers addressed directly to Jesus, not to the Father.

As another Churchman, I request "A" to point out any example or authority in the Gospels or Epistles for this practice.

B. 


\section{Bethke}

\section{Appendix 3}

\section{Review of Colenso's Collections of Psalms and Hymns in The Church Times}

The Church Times, Oct. 1866, 326

\section{Reviews}

Psalms and Hymns for use in the Church of England, at Home and in the Colonies. 32mo. London: George Bell. 1853.

Psalms and Hymns for use in the Cathedral Church of St Peter's, Maritzburg. 18mo. Pietermaritzburg: Davis. 1866.

That Dr Colenso has twice appeared as the compiler of a hymnal is sufficiently well known, and attention has lately been drawn to the face that the second collection is of an ultra-Socinian character, going, in truth, far beyond the English Unitarian school as represented by Mr Martineau. But that section of the so-called Broad Church party in this country which combines unscrupulous championship of Dr Colenso and wilful slander of Bishop Gray with the leadership of the Anti-Ritual war of extermination, is always prepared to meet every charge brought against their ex-prelate of Natal with simple denial and to allege that it is the mere invention of sectarian malice. Of course, this policy will be, or has been, pursued in the matter of the Hymn-book, and as copies are not likely to reach this country in large numbers, the scandal will be hushed up as far as possible. To counteract any such ingenuity, we have been at pains to obtain both books from Natal, and we proceed to lay before our readers some of the most glaring discrepancies between them. The earlier book, drawn up when the compiler was rector of Forncett St Mary, in the diocese of Norwich, contains three hundred and fifty hymns, inclusive of a hundred metrical versions of Psalms. At the first glance it appears just the same as the average compilations of the Evangelical school, though perhaps more deficient in fervour than the best of them are, but on the other hand, arranged more in conformity with the Calendar of the Prayer Book. Advent, Christmas, Circumcision, Epiphany, Lent, Easter, Ascension, Whitsuntide, and Trinity are provided for. A small number of Festival Hymns follow, to wit: All Saints, Michaelmas Day, Purification, and Annunciation. Then Ember Days, Baptism, Confirmation, Holy Communion, Burial of the Dead, Foundation and Consecration of a Church, Charity Sermons, New Year, Harvest Thanksgivings, For the Queen, Public Fast, Church Missions, Hymns for those at Sea, and Miscellaneous. There are many well-known favourites in the book, and its defects in depth of teaching and variety are very much more due to omission of the class of hymns and the doctrinal statements common in High Church hymnals than to any neglect of the other school. And it derives only nine pieces from ancient sources, unless we may count four or five versions of the Veni Creator separately. The utterances of Holy Baptism and Holy Communion are just what one finds in Kemble, Bickersteth, and the like, and on the whole the book proves, on further examination, to be what it seemed at first, a moderate Low Church compilation. There is, however, no hesitancy of expression as to the Most Holy Trinity, and the perfect Godhead of Christ. It is needless to multiply examples, and citation of a few well-known hymns as proof will suffice. Thus, we find the following: "The Advent of our God," Adeste fideles, "When 


\section{Bethke}

I survey the wondrous Cross"; "Jesus Christ is risen to-day"; "Father of Heaven, Whose love profound"; "My God and is Thy table spread" and so forth.

Now let us take the issue of 1866 . First as to its mere structural arrangements. It contains one hundred and 52 pieces only, amongst which the metrical Psalms are interspersed, instead of forming a separate group at the beginning, as in the former hymnal. Next, the division of Seasons and special occasions is omitted, and the hymns are not subjected to any such classification as before. It is true that an index professes to point out what hymns are suitable for the various seasons and services, but they are not grouped, and in most instances, it is not easy to discover any connection between the hymn indicated and the occasion for which it is intended to serve. One thing can, however, be still said for Dr Colenso. He has not, so far as this Hymn-book is concerned, denied the doctrine of the Trinity. There is one hymn (59) which contains the line "Praise the mystic Threein-One," a similar phrase is in No. 78; and the last line of No. 143 is "Praise Father, Son, and Holy Ghost." And it is but just to allow him all "that much expressions imply, though the presence of a piece like Heber's "Holy, Holy, Holy, Lord God Almighty," proves nothing, for it does not contain anything to which a Socinian would object. But this is the sole hint throughout the book of any tenet which a Jew, a Unitarian, or for that matter, a Mohammedan might not accept. The charge that the Name of Jesus or Christ does not occur from one end of the volume to the other is perfectly true. Not only so, but the doxology quoted above, and the line "Forgive me, Lord, for Thy dear Son," in Ken's Evening Hymn (No. 16), are the only phrases that can be fairly construed as containing any reference to Him whatsoever. There are, no doubt, passages which a devout Christian would interpret to himself as pointing to the Incarnate Saviour, but there is not the faintest viable reason why a non-Christian should not interpret them in a totally different way. What best illustrates the moral obliquity of Dr Colenso in the matter is the way in which he attempts, by means of the index, to throw dust into the eyes of his readers. We are referred in it to certain hymns suitable for Advent, Christmas, and Easter. Now supposing those seasons to be kept at all by professing Churchmen, it might fairly be expected that the first would contain special mention of our Lord's first and second coming, the next a notice of His Birth, and the last the story of His Resurrection. Not a bit of it. There is not so much as a hint of the three, save in one case which we will quote immediately. Three hymns are specified for Advent, 118, 128, 151. The first of these is a metrical version of Psalm CX., the second is a paraphrase of a few verses of Isaiah XI., and the third is Doddridge's "Ye servants of the Lord." All perfectly unimpeachable in themselves, if they were to be supplemented by something fuller, which they are not. Christmas, in its turn, has three hymns, 14, 109, 111. The first of these does contain an allusion which may, but need not, be interpreted of Christ. To be quite sure of doing no injustice, we will give it entire. 


\section{Bethke}

Give to our God immortal praise;

Mercy and Truth are all His ways;

Wonders of Grace to God belong,

Repeat His mercies in your song.

He fills the sun with morning light;

He bids the moon direct the night;

His mercies ever shall endure

When sun and moon shall shine no more.

He sent His Word with power to save

From guilt and darkness and the grave;

Wonders of Grace to God belong

Repeat His mercies in your song.

Through this vain world He guides our feet,

And leads us to His Heavenly seat;

His mercies ever shall endure

When this vain world shall no more.

Of course, the italicised lines may be explained of the Incarnation or Atonement by anyone who pleases, but it proves, on comparison with the earlier book, to be only a paraphrase of Psalm CXXVI. Hymn 109 is a paraphrased cento from Psalm XCVI., and so is 111 from Psalm XCVII.

Easter-tide is fitted with four hymns, $84,109,110,111$. Two of these have already done duty for Christmas, so only the remaining pair has to be examined. 84 is a metrical version of part of Psalm CXVIII. 110 is a version of the first five verses of Psalm XCVIII. The ten hymns which serve for Lent do not contain the most distant allusion to the origin of that season, or the sacred Passion which ended it. Ascension-tide, which had two Psalms and ten hymns assigned it in the book of 1853, is not so much as named in that of 1866. Four hymns are appointed for Whitsuntide, 2, 30, 84, 109. Two of them we have had before. The other do not so much as contain the word Spirit, or anything like it. There were, as we remarked above, several versions of the Veni Creator in the book of 1853. Not one, even paraphrased and diluted, occurs in that of 1866. The omission of any classification has been, apparently, of set purpose. Had the metrical Psalms been collected apart, or even headed with any mark of their origin, no one would fail to be struck with the very scanty proportion of distinctively Christian hymns which remain when sifted from the Old Testament productions. Some of the pieces are so far paraphrased that we cannot be always sure of recognising them, but as nearly as we can decide, no less than ninety out of the hundred and 52 pieces are taken from the Psalms, the same Psalm often doing duty in two or three versions, and at least a dozen other hymns are drawn from Old Testament sources. That leaves only fifty hymns to represent positively Christian faith and hope, and as consummate care has been taken to exclude from even that small number anything which can bring the Founder of Christianity to mind, by adopting colourless hymns as a rule, and by altering and mutilating the few which had anything distinctive about them, the result may readily be conceived. In fact, there are but three hymns in the whole compilation $(30,47$, and 124) which so much as 


\section{Bethke}

draw an image from New Testament diction. One of these (47) is from a Wesleyan collection, and the verse runs:

He, that on the throne doth reign,

Them for evermore shall feed,

With the tree of life sustain,

To the living fountains lead.

The passage in Revelation vii. 17 is "The Lamb which is in the midst of the throne shall lead them," \&c. The omission of this, the leading idea of the paragraph, is not significant amongst Wesley's hymns because there are several others which supply the lacking thought, but here we have nothing of the kind. No. 124 is a New Year hymn based on the parable of the barren fig-tree spared for another season, but it contains no specifically Christian allusion. No. 30 is the well-known hymn "How beauteous are their feet" and it too contains a phrase or two from the New Testament, but nothing in the least definite. It says that we have something which prophets and kings longed for, but does not say what.

Furthermore, the excuses which Dr Colenso put out lately in the columns of the Times were insincere and dishonest. He alleged that direct prayer to our Lord is discouraged by the English office-book, and by the Presbyterian hymnal in Scotland, and that he was merely trying to carry out their teaching by expunging hymns of dubious orthodoxy from his compilation. Not to dwell on the too obvious fact that he must have known himself to be stating a wilful falsehood in the assertion he made as to the Prayer Book, seeing how very plain the Litany alone is on the subject, and that he has been at least grossly careless as to the Scotch hymnal, which contains not less than thirty such pieces as those he disapproves, he has misrepresented the point at issue as to himself. It is not merely that he has excluded hymns to Christ from the book, but hymns about Christ. There is nothing like — no, not in the faintest comparison possible — as much about Him in Dr Colenso's hymnal as there is about the Blessed Virgin in an ordinary Dissenting book of scared song. Mr Martineau has no difficulty in referring to events in the Gospel History, but no person extern to Christianity, taking up the Natal book, would gather a hint from it that such a Being as Christ ever existed, or that there was any appreciable difference between belief of Christians and that of Fire-worshippers. And in the face of that plain fact, no words are adequate to express the scorn which every honest man must feel for such a miserable equivocation as that with which Dr Colenso has sought to vindicate himself. 